\title{
ECONOMICS
}

\section{HIGH-SKILLED MIGRATION IN TIMES OF GLOBAL ECONOMIC CRISIS}

\author{
by
}

\author{
Mathias Czaika \\ International Migration Institute \\ University of Oxford \\ and
}

Christopher Parsons

Business School

University of Western Australia 


\title{
HIGH-SKILLED MIGRATION IN TIMES OF GLOBAL ECONOMIC CRISIS
}

\author{
by \\ Mathias Czaika \\ International Migration Institute \\ University of Oxford \\ and \\ Christopher Parsons \\ Business School \\ University of Western Australia
}

DISCUSSION PAPER 16.16

\begin{abstract}
We introduce two pioneering databases in order to analyze the implications of the Global Economic Crisis on international migration. The first details inflows of migrant workers of 185 nationalities to 10 OECD destinations, disaggregated by skill level (highly skilled and otherwise), between 2000 and 2012. The second comprises immigration policies implemented by 19 OECD countries between 2000 and 2012. We distinguish between six skill-selective admission policies, six post-entry policy instruments and three bilateral agreements. Subsequently we present preliminary analysis of these data against the backdrop of the Global Economic Crisis. The Global Economic Crisis negatively affected annual inflows of both highly and other skilled migrants between 2007 and 2009, although they resumed their upward trend thereafter. The starkest trends in policy terms include: the emergence and rapid diffusion of student job seeker visas, the relative stability in the prevalence of skill selective policies in the wake of the Global Economic Crisis, a greater use of financial incentives to attract high-skilled workers and increased employer transferability for migrants at destination.
\end{abstract}

Author: Mathias Czaika, International Migration Institute, University of Oxford, mathias.czaika@qeh.ox.ac.uk

Christopher Parsons, UWA Business School, University of Western Australia, christopher.parsons@uwa.edu.au

\section{The IMI Working Papers Series}

(IMI Working Papers Series 2016, No. 126)

The International Migration Institute (IMI) has been publishing working papers since its foundation in 2006. The series presents current research in the field of international migration. The papers in this series:

- analyse migration as part of broader global change

- contribute to new theoretical approaches

- advance understanding of the multi-level forces driving migration

This paper is published by the International Migration Institute (IMI), Oxford Department of International Development (QEH), University of Oxford, 3 Mansfield Road, Oxford OX1 3TB, UK (www.imi.ox.ac.uk).

IMI does not have an institutional view and does not aim to present one.

The views expressed in this document are those of its independent author. 


\section{Contents}

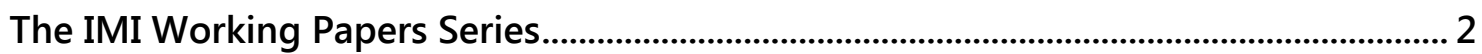

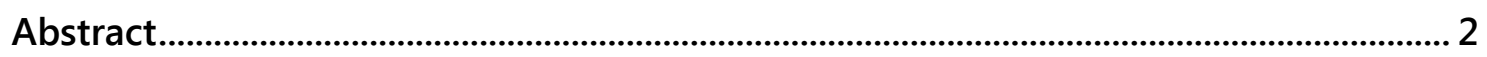

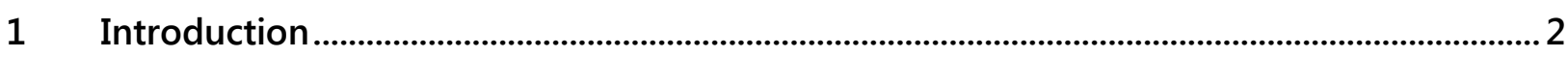

2 High-skilled migration flow data: methodology.......................................................................... 4

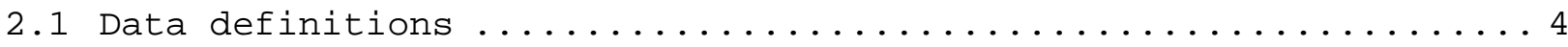

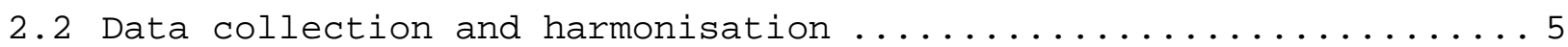

3 International skilled labour flows before and after the global economic crisis.................. 6

3.1 High-skilled migration policies before and after the global economic crisis ........................... 7

3.2 Skill-selective admission policies since $2000 \ldots \ldots \ldots \ldots \ldots \ldots . .8$

3.3 Post-entry migration policies since $2000 \ldots \ldots \ldots \ldots \ldots \ldots \ldots \ldots \ldots 10$

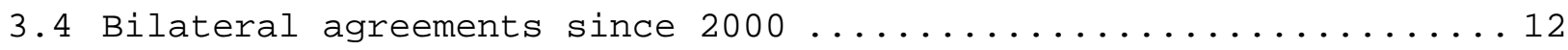

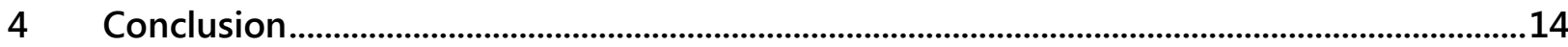

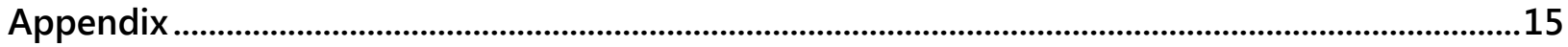

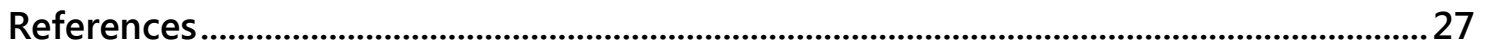




\section{Introduction}

Immigration today is a controversial issue in most (industrialised) countries globally. Public debate and policy making have become characterised by a stark contrast between restrictive attitudes towards lowskilled immigration and more liberal views pertaining to the immigration of high-skilled workers. Since the late 1990s, countries have intensified their efforts to recruit and retain international talent, a trend largely driven by the general perception that highly qualified workers are net contributors to receiving societies, by promoting innovation and national competitiveness and thus contributing to long-term economic growth.

The global financial crisis in 2007, largely the result of the US housing market collapse, triggered sharp falls in output and rising unemployment in most industrialised countries. Public and private sectors laid off large numbers of workers, introduced low (or zero) hours contracts and ceased recruitment efforts. After deep recessions, most industrialised countries have returned to modest growth, although unemployment rates remain relatively high. The crisis most adversely affected the wages and employment of (highly) skilled personnel in banking, IT and aligned sectors, although high-skilled migrant workers were considered those most directly hit (ILO 2009, Castles and Miller 2010). Despite these conjectures, the impact of the global economic crisis on high-skilled migration flows to industrialised economies has not been systematically assessed, mainly due to the lack of suitable data. This study explores the extent to which the crisis has affected high-skilled migration to major industrialised countries and whether the (pre-crisis) optimism pertaining to high-skilled immigration, as reflected by increasingly liberalised high-skilled immigration policies before 2007, has been reversed towards greater restrictiveness afterward.

We analyse the effects of the global economic crisis on the trends and dynamics of high-skilled migration to 10 OECD countries and high-skilled migration policies in 19 OECD countries; thereby contributing to the burgeoning literature on high-skilled migration and policy making (e.g. Lowell 2005, Bhagwati and Hanson 2009, Chaloff and Lemaitre 2009, Kahanec and Zimmermann 2011, Wiesbrock and Herzog 2010, Chiswick 2011, Boeri et al. 2012, Boucher and Cerna 2014, Koslowski 2014, Parsons et al. 2014, Cerna and Czaika 2016, Czaika and Parsons 2015). Our analysis draws upon two new datasets comprising high-skilled migration flows and policies, compiled under the auspices of the Drivers and Dynamics of High-Skilled Migration (DDHSM) project at the University of Oxford. We outline the conceptual and practical challenges when analysing the international flows of skilled workers and the potential roles of skill-specific migration policies. In this regard, this study represents a first attempt to provide an empirical foundation for understanding high-skilled migration processes and policy developments across major destinations during the first decade of the twenty-first century.

While (bilateral) migration stock and flow data have been made increasingly available in recent years, bilateral migrant flow data, disaggregated by skill level, have remained conspicuously nonexistent. The paucity of these data inhibits many avenues of academic research, including understanding the drivers and dynamics of migration patterns and, perhaps above all, precludes a judicious assessment of the efficacy of (high-skilled) migration policies. We address this notable gap by examining immigration data of labour flows by skill, derived from administrative sources from across 10 OECD destination countries, ${ }^{1}$ over the period $2000-2012$. Given the discrepancies that exist across destination countries' occupational classifications (Parsons et al. 2014), a major contribution of the study is in harmonising the data to a common definition of what it means to be high-skilled (or otherwise).

\footnotetext{
${ }^{1}$ Australia, Canada, Israel, Korea, New Zealand, Norway, Sweden, Switzerland, the UK and the US.
} 
Bilateral stock data provide snapshots at particular moments in time of the total numbers of immigrants residing in a particular destination. The compilation and subsequent analysis of bilateral stock data are aided by fairly standardised questions posed by a moderately limited set of primary sources, typically national censuses or population registers (see for example Harrison et al. 2003, Parsons et al. 2007, Özden et al. 2011). ${ }^{2}$ Bilateral stock data disaggregated by skill are scarcer, but nonetheless most countries that conduct censuses pose questions regarding individuals' education and occupation, the former of which have been compiled in Docquier and Marfouk (2006), Docquier et al. (2009), Brücker and Marfouk (2013) and Artuç et al. (2014). Bilateral stocks disaggregated by both education and occupation are documented in Dumont and Lemaitre (2004), Dumont, Martin and Spielvogel (2007) and Arslan et al. (2014).

Figure 1 Total high-skilled migrant stocks, aged 15+, in 9 OECD destinations, 2000 and 2010

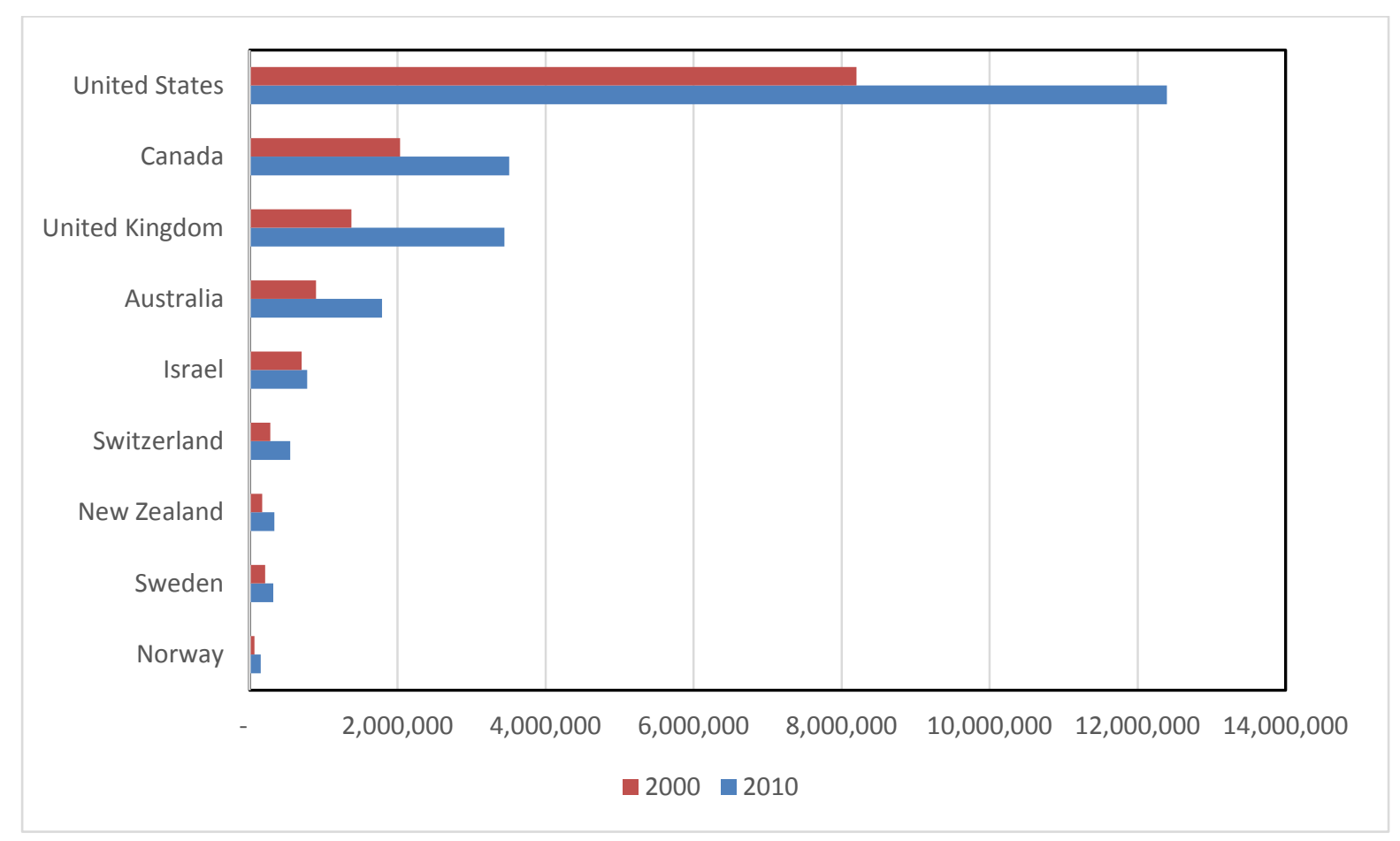

Source: DIOC database 2000 and 2010, DIOC-E database 2000

Figure 1 shows comparable data on the total stock of high-skilled (i.e. tertiary-educated) migrants for nine of our 10 OECD destinations in the years 2000 and 2010 (data for Korea is not available). The vast majority of highly skilled migrants agglomerate in OECD countries (Artuç et al. 2014) and Figure 1 further demonstrates that within this select group of nations a few countries account for the majority of high-skilled workers. The US is the outlier in terms of absolute numbers of high-skilled foreign-born workers, although Canada, the UK and Australia all fare relatively well. Importantly, it is also these four countries that have experienced the greatest absolute growth in their high-skilled stocks between 2000 and 2010, meaning that the existing inequalities (see Özden and Parsons 2015) are being compounded over time and have even increased despite (or because of) the global economic crisis.

Immigration flow data provide information on the number of immigrants entering a country on a frequent - typically annual - basis; such that they are superior to stock data when analysing short-run fluctuations in migration. Whereas most countries conduct censuses or utilise population registers to

\footnotetext{
${ }^{2}$ Notably the US abandoned the national census in 2000. It has since been replaced by a number of rolling surveys, including the American Community Survey.
} 
collect migrant stock data, fewer countries collate immigrant flow data. Nevertheless significant progress has been made in the compilation of aggregate bilateral immigrant flows, for example Ortega and Peri (2013), United Nations (2013) and Vezzoli et al. (2014). ${ }^{3}$ Very few countries record the skill composition of incoming migrants, however, and when recorded, immigrants' occupations are most commonly documented.

A key contribution of this study is to compile immigrant flow data from national, largely administrative sources, for 10 OECD destination countries, disaggregated by nationality and occupation. These data are subsequently harmonised to a standardised definition: long-term labour migrants, defined by their nationality, those gaining entry to destinations based strictly upon their occupation (i.e. for work) and applying for visas from outside of the country of destination. In total, the dataset captures almost 9.3 million high-skilled labour migrants over the period 2000-2012. ${ }^{4}$ Across the years 2003-2008, the years for which the panel is balanced, our data capture on average three-quarters of a million high-skilled migrants.

\section{High-skilled migration flow data: methodology}

\subsection{Data definitions}

Although many migrant types do not have their skill level recorded, economic migrants who enter destination country labour markets often have their occupation documented upon entry. In this study we therefore adhere to a definition of 'labour migrant'. We define a high-skilled migrant as an individual working in an occupation that falls into the first three categories of the International Standard Classification of Occupations (ISCO): (1) managers, senior officials and legislators, (2) professionals and (3) technicians and associate professionals; those employed in jobs commensurate with a tertiary or graduate education (see Parsons et al. 2014 for further details).

Migrants' origins are typically recorded by their country of birth, nationality or country of previous residence. Stock data typically rely on the first two. Immigrant flow data often build upon all three. One broad advantage of flow data is that by definition they imply movement across international borders. Another advantage is that by definition, flow data record legal migrants as opposed to stock data that often capture an unknown proportion of illegal migrants. Since labour migrants' right to work is a function of their nationality, we adopt this definition.

Immigrants are further termed temporary or (long-term) permanent. The United Nations defines a long-term migrant as an individual that resides abroad for 12 months or longer (UN 1998). We adopt this definition, since countries issue visas that often imply differing lengths of stay and maintaining consistency in terms of migrants' duration of stay proves essential for the sake of comparability.

While it is natural to consider migrant inflows to imply movement across an international border in the year in which they are recorded, in fact the available data instead reflect that a movement must have taken place at some point, since migrants having already entered a destination country may instead change their legal status. In the US this difference is between 'arrivals' and those obtaining permanence by adjusting their status. In the UK, individuals coming from abroad for employment are granted 'work permits', while those individuals that instead transfer to employment status are granted 'first permission'

\footnotetext{
${ }^{3}$ See DEMIG project (University of Oxford) for more detailed information on the C2C flow data (http://www.imi.ox.ac.uk/projects/demig)

${ }^{4}$ This panel dataset is slightly unbalanced, with some missing country years at the beginning and the end of the decade.
} 
to work. Given the stark differences that arise, our data refer to labour migrants arriving from outside the destination country to the greatest possible extent.

In sum, we adhere to the greatest possible extent to labour migration and define migrants by their nationality and occupation. We focus upon immigrants that arrive with the intention of staying at least 12 months and omit those that are recorded having changed status to one of employment. Given that destination countries variously adopt competing occupational nomenclatures, we adopt a broad definition of what it means to be highly skilled, one that includes the first three major groups of the International Standard Classification of Occupations (ISCO) 2008 classification.

\subsection{Data collection and harmonisation}

Immigrant flow data are recorded for varying purposes, by different government ministries using a variety of survey tools. ${ }^{5}$ Flow data disaggregated by skill, often recorded using administrative tools, are typically deemed sensitive and data documented at greater levels of disaggregation are considered even more delicate. National points of contact cited issues of privacy - concerns that specific individuals could be identified from the data - as the primary reason why data were unavailable. When making requests, therefore, it proved vital to obtain as detailed data as was feasible, while not applying for too much data, the result of which would be to have terminated any application. It therefore did not prove possible - in those cases where such data existed - to obtain many additional variables of interest, for example data on immigrants' age. ${ }^{6}$

To standardise immigrants' length of stay (of 12 months and over) to the greatest possible extent, those entering countries on shorter term visas were dropped from the dataset, along with students, entrepreneurs, investors and business visitors; the former since our focus is on destination country labour markets, the remainder since the period of stay and precise occupations of those individuals remain unclear. We additionally dropped those not in employment. In cases where visa types had ambiguous lengths of stay, we chose those data pertaining to migrants staying at least 12 months. One exception was made in the case of the US, for which we combined data on issuances of permanent residence with I-94 H1B visa data. ${ }^{7}$ In a few country instances, small numbers were rounded for considerations of privacy, but in all instances, 'true zeroes' are maintained in the data.

For each destination, we chose the data source that offered the greatest opportunity for harmonising occupations across countries. As shown in the appendix (Table A1), the sources drawn upon are varied and include administrative data files (Australia, Canada, Israel, New Zealand, the US), work or residence permits (Switzerland, UK), population and employment registers (Norway, Sweden) and employment visas (Korea). A major challenge (and therefore a significant contribution) of this dataset is the adoption of a harmonious definition of human capital based on immigrants' occupation. Building upon Parsons et al. (2014), we adopt a broad notion of human capital that comprises the first three major groups of the International Standard Classification of Occupations (ISCO) 2008: (1) managers, senior officials and legislators, (2) professionals and (3) technicians and associate professionals. We include

\footnotetext{
${ }^{5}$ A discussion of these different survey tools is beyond the scope of this chapter and interested readers are referred to Bilsborrow et al. (1997).

${ }^{6}$ Given that the data in this chapter are disaggregated by occupation, it is safe to assume that all individuals that had their occupation recorded must at least be of working age.

${ }^{7}$ We assume that all those receiving H1B visas are highly skilled in the absence of an occupational breakdown. In the absence of a Freedom of Information request the only data available on incoming H1B holders were I-94 admissions data. These figures no doubt overestimate the total income number of high-skilled migrants to the US in a particular year, but their inclusion was deemed more important than their exclusion.
} 
group 3, since otherwise a large number of science and technology occupations including 'computer network and systems technicians', 'telecommunications engineering technicians' and 'information and communications technology user support technicians' would be excluded. Also shown in Table A1, and as discussed in greater detail in Parsons et al. (2014), occupational classifications vary between and within countries over time. To concord the data, each national nomenclature was compared to the ISCO 2008 classification at the greatest level of disaggregation possible (see Appendix A2 for greater detail).

Since immigrants entering countries for employment are often recorded by nationality, the resulting data set benefits from a standardised definition of migrants' origins. ${ }^{8}$ Another particular advantage of using a definition based upon nationality, is that migrants' nationalities are precisely recorded in the primary data, thereby allowing us to assign almost every immigrant to a specific country of origin. In all we delineate 185 nationalities, which include qualifying the Soviet Union, Czechoslovakia and Yugoslavia as single entities. The full list of countries can be found in Appendix A3.

\section{International skilled labour flows before and after the global economic crisis}

Figure 2 displays skill-based immigration flows into 10 major OECD countries, which reveals over the entire period of 2000-2012 an increasing trend in the number of annual inflows of both high-skilled (ISCO 1-3) and non-high-skilled (ISCO 4-9) immigrant workers. The average inflow of high-skilled migrants into those 10 destinations $^{9}$ has steadily increased between 2003 and 2006/2007 before a short but steep decline of about 20 per cent between 2007 and 2009 interrupted this longer-term upward trend in high-skilled immigration. However, from 2010 onwards overall inflow picked up again only to continue the pre-crisis trend between 2003 and 2007, despite the fact that unemployment rates remained on relatively high levels compared to the pre-crisis period.

Non-high-skilled immigration numbers followed a similar dynamic with an increasing trend (though at a lower rate) between 2003 and 2006/2007 and a brief but moderate decrease immediately after the outbreak of the crisis in 2007. Interestingly, non-high-skilled occupations seemed to be less affected by the crisis as the average inflow of this type of migrant workers into these 10 major OECD destinations declined only by about 10 per cent between 2006 and 2009, recovering in 2010 to pre-crisis levels. The skill composition of immigrant inflows declined between 2001 and 2008 from 60 per cent to 51 per cent high-skilled migrants in all incoming labour migrants. After 2009, this trend slightly reversed with the share of high-skilled migrants among all labour migrants entering the 10 destination countries rising back to 56 per cent in 2011.

Due to the dominance of US high-skilled immigration even among these top OECD destinations, Figure 2 reflects largely the overall trends and fluctuations in the US, which is not representative for all of these 10 destinations. High-skilled immigration flows to countries like Korea, Israel or New Zealand have been largely unaffected during the global economic crisis, although at least New Zealand has seen a significant increase in its unemployment rate in 2009 and after. Interestingly, Australia and Canada,

\footnotetext{
${ }^{8}$ The only exception is the data for Israel, which are based upon the country of birth. The vast majority (74 per cent) of immigrants to Israel over the period, however, originated in the countries of the former Soviet Union, which is recorded as a single entity in the dataset.

${ }^{9}$ For the periods 2000-2002 and 2009-2012, our dataset captures only 9 (8) countries due to data availability. In the case of Norway, occupation data for 2000-2002 were incomparable with those of later years. For Sweden, data after 2009 were unavailable. In the Swiss case, the residence permit data only began in 2002 and for the UK, the work permit data series terminated in 2008.
} 
which are the next major destinations for high-skilled migrants after the US, experienced a minor decline in inflows only after 2010.

Figure 2 Unemployment and average immigration flows into 10 OECD destinations, 2000-2012

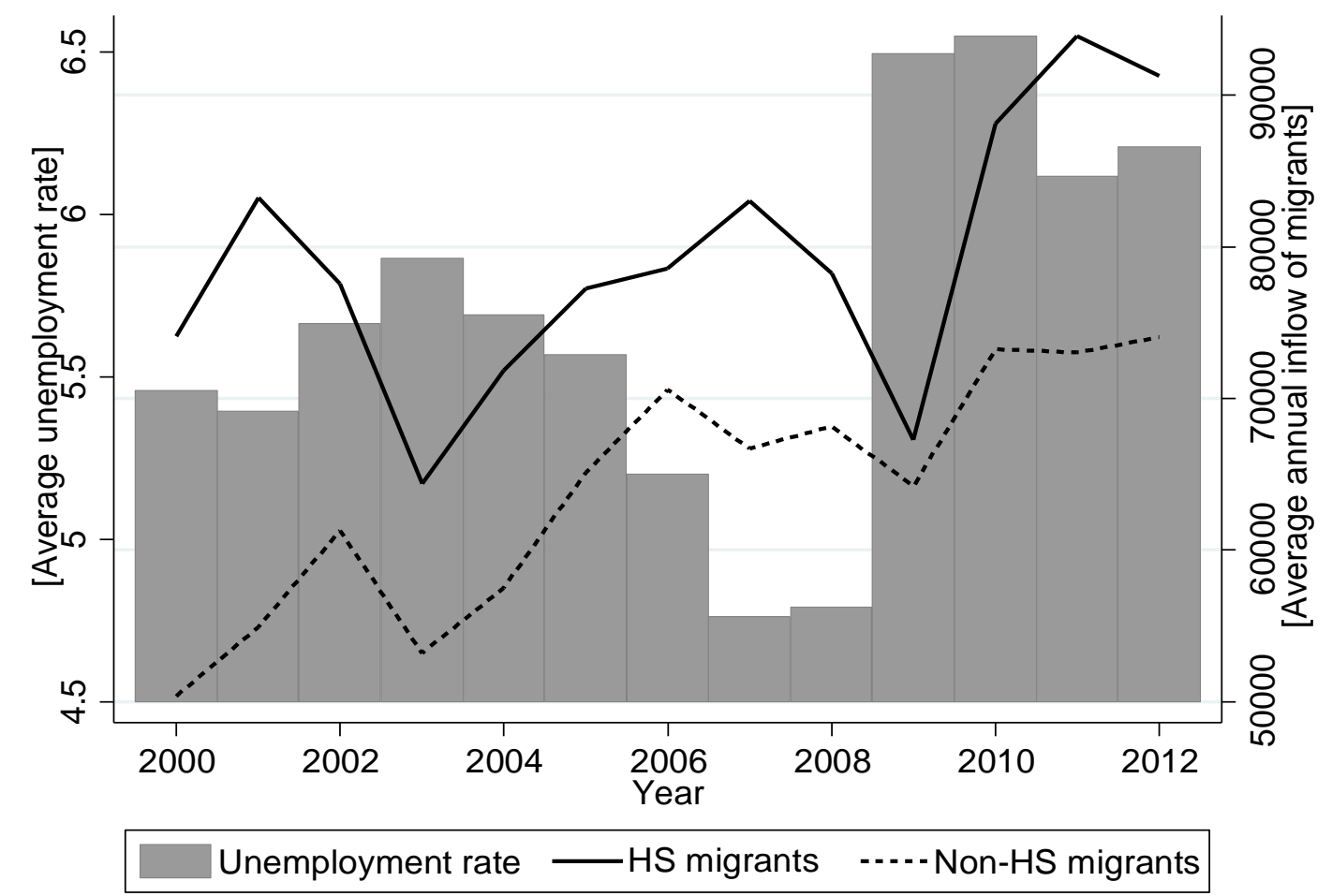

Overall, the drop in annual immigration flows into major OECD countries after 2007 was rather shortlived and not very significant for most destinations. The US, as the major destination in absolute terms, was probably most affected, while other destinations either had a minor or no drop in the number of highskilled immigrants. This trend in overall flows largely reflects the significant increase in high-skilled immigrant stocks between 2000 and 2010 in all of these destinations. Although business cycles and respective labour market situations may have some impact on the attractiveness of a destination, other rather longer-term factors seem at least equally important in driving international processes of highskilled migration. Immigration regulations and policies are generally seen as decisive in influencing not only the attractiveness of immigrant destinations but also affecting the actual volume and composition of the migration influx. Obviously, such political factors are endogenous in the sense that policy makers may respond to labour market supply and demands and migration trends either by fine-tuning certain administrative regulations or by initiating major policy reform in order to re-design the immigration system more substantially. We explore this political dimension in more detail in the next section.

\subsection{High-skilled migration policies before and after the global economic crisis}

Policies seeking to attract and select talented migrant workers are proliferating across the globe. As of 2013, 40 per cent of (172) UN members and two thirds of OECD countries aim to increase the numbers of high-skilled immigrants (Czaika and Parsons 2015). Only a limited number of countries have actually implemented and institutionalised the necessary legal provisions to attract and select high-skilled migrants in significant numbers, however. The effectiveness of such policies may nevertheless be 
relatively small in comparison with other social, economic and determinants (Czaika and de Haas 2013), an evaluation of which is presented in Czaika and Parsons (2015).

Well-executed immigration regulations are nonetheless widely perceived to strengthen countries' abilities to attract globally mobile skilled workers. Engaging in the global competition for skills, industrialised and knowledge-based economies remain under pressure to develop strategies that prove effective in attracting, selecting and retaining high-skilled immigrants (Doomernik et al. 2009, OECD 2008). Concurrently, in an environment of rising concerns on immigration (Duffy and Frere-Smith 2014), electorates typically expect foreign workers to fill labour market shortages, should they be unable to be filled by domestic workers, and make a net contribution to the public purse. A core underlying principle for admitting foreign workers in many countries is migrants' employability. Consequently, a key challenge is to recruit skilled foreign workers for hard-to-fill occupations. These workers are often in privileged positions as they are able to select from among numerous employment opportunities, which leads to a process of 'mutual selection' between destination countries' policies and in-demand migrants. In this context, it is unlikely that a specific policy instrument per se results in a country becoming more or less attractive to high-skilled migrants, but rather it is a larger set of immigration policy instruments in combination with other public policies serving this same purpose (Papademetriou et al. 2008, Papademetriou and Sumption 2013).

In this study, we investigate the degree to which 15 (skill-based) migration policies, both unilateral and bilateral, have been implemented in 19 OECD countries between 2000 and 2012. ${ }^{10}$ We divide these instruments into three groups that are: i) six skill-selective admission policies: quotas, shortage lists, job contingency requirements, labour market tests, points-based systems and student job seeker visas, ii) six post-entry policy instruments: employer portability rights, immediate family reunion rights, spousal work rights, permanency rights, financial incentive schemes, labour market protection regulations, and iii) three types of bilateral agreements on double taxation, diploma recognition and social security including pension portability. These longitudinal data are derived from the texts of laws, the annual SOPEMI reports of the OECD, the DEMIG Policy database (http://www.imi.ox.ac.uk/data/demigdata/demig-policy-1), the 'Migration News' database based at UC Davis (https://migration.ucdavis.edu/mn/) and government websites, in addition to other resources detailing migration opportunities. Each policy instrument is coded as one if a certain policy exists in a particular country-year and zero otherwise (see Appendix A4 for more details on coding).

\subsection{Skill-selective admission policies since 2000}

In recent years, OECD, and to a lesser extent non-OECD, governments have implemented policies aimed at selecting highly qualified immigrants to fill immediate (short-term) domestic labour shortages and address structural (i.e. long-term) employment in specific sectors (e.g. health, ICT sector, STEM subjects). Labour immigration policy systems can broadly be separated into those that require labour migrants to have acquired a job offer prior to entry (i.e. short-run policies), and those that implement points-based systems (i.e. long-run policies).

In short-run business-driven immigration policy systems, employers usually take an active role in recruitment by sponsoring foreign workers to qualify for temporary or permanent work permits. The job contingency principle ensures foreign workers' employability in the domestic labour market. Despite being relatively effective in selecting foreign workers to fill immediate labour market shortages, the job offer requirement may also deter migrants who, despite being highly qualified, fail to address immediate

\footnotetext{
10 These countries are: Australia, Canada, Czech Republic, Denmark, Finland, Germany, Israel, Japan, Korea, New Zealand, Norway, Poland, Portugal, Romania, Slovakia, Sweden, Switzerland, the UK, the US.
} 
labour market shortages (Czaika and Parsons 2015). Most European immigration systems, (including the European Blue Card) and US temporary work visas are based upon the job offer principle, whereby employers often first submit work permit requests to local, national, or even Europe-wide labour market tests; case-by-case assessments of labour market shortages shall ensure that no 'equivalent' domestic workers are available. The bureaucratic burden of labour market tests can be significant. Various countries have therefore developed occupational shortage lists, which exempt employer-sponsored migrant workers from labour market tests. Shortage lists may thus accelerate recruitment, particularly when entire occupations cannot be filled domestically. The stringency of the underlying analysis used to identify labour market needs has been criticised however since they may be premised on politically motivated decisions (Sumption 2013).

In long-run migration policy systems, human capital is assessed on an individual basis through points-based systems (PBS) in which applicants are awarded points based upon their qualifications, age, work experience, language skills and earning potential. Job offers are generally not required, although they may privilege migrants that have already secured employment in advance of entry. Canada and Australia (since 1967 and 1989, respectively) pioneered these systems, which aim to attract high-skilled migrants in great numbers. More recently, however, these systems have been shown to admit migrants that fail to address severe labour market shortages and may thus produce inefficient labour market outcomes in terms of under- or inadequate employment (Aydemir 2013). This observation provides the motivation for further awarding points for securing employment in advance and filling employment opportunities that feature on occupational shortage lists. Most countries implementing points-based systems thus increasingly aim to implement hybrid policy systems that combine elements to ensure immigrants' successful employability. Nevertheless, points-based systems are increasingly perceived as relatively effective in attracting high-skilled migrants in large numbers (Facchini and Lodigiani 2014, Czaika and Parsons 2015).

The recruitment of students also represents an increasingly popular strategy to attract skilled labour. Policies include the provision for foreign students to remain post-graduation, which constitute efficient means to recruit high-skilled migrants at relatively low social and labour market integration costs. Most Western countries therefore offer student job seeker visas that allow graduates to search for employment, typically for between six and 24 months, during which time foreign graduates can qualify to meet the standard criteria for regular high-skilled employment. Some countries provide additional provisions for transition from study into regular (temporary or permanent) employment by exempting foreign students from some commonly stipulated work permit requirements.

Overall, admission numbers are often managed through quotas of temporary or permanent work visas. These numerical ceilings are usually set on an annual basis, such as in the case of the H1-B visa in the US. Various European countries such as Austria, the UK, or Norway apply specific quotas determining the maximum number of third-country nationals who may enter and take up employment. Each country employs a different system ranging from 'soft limits' (e.g. Norway) to more rigorous limitations (e.g. Austria) (EMN 2013). Quotas are often set in relation to the size of the national labour force, the resident population, the number of residence permits and work permits, or an assessment of the current labour market situation (EMN 2013). 
Figure 3 Skill-selective admission policies in 19 destination countries, 2000-2012

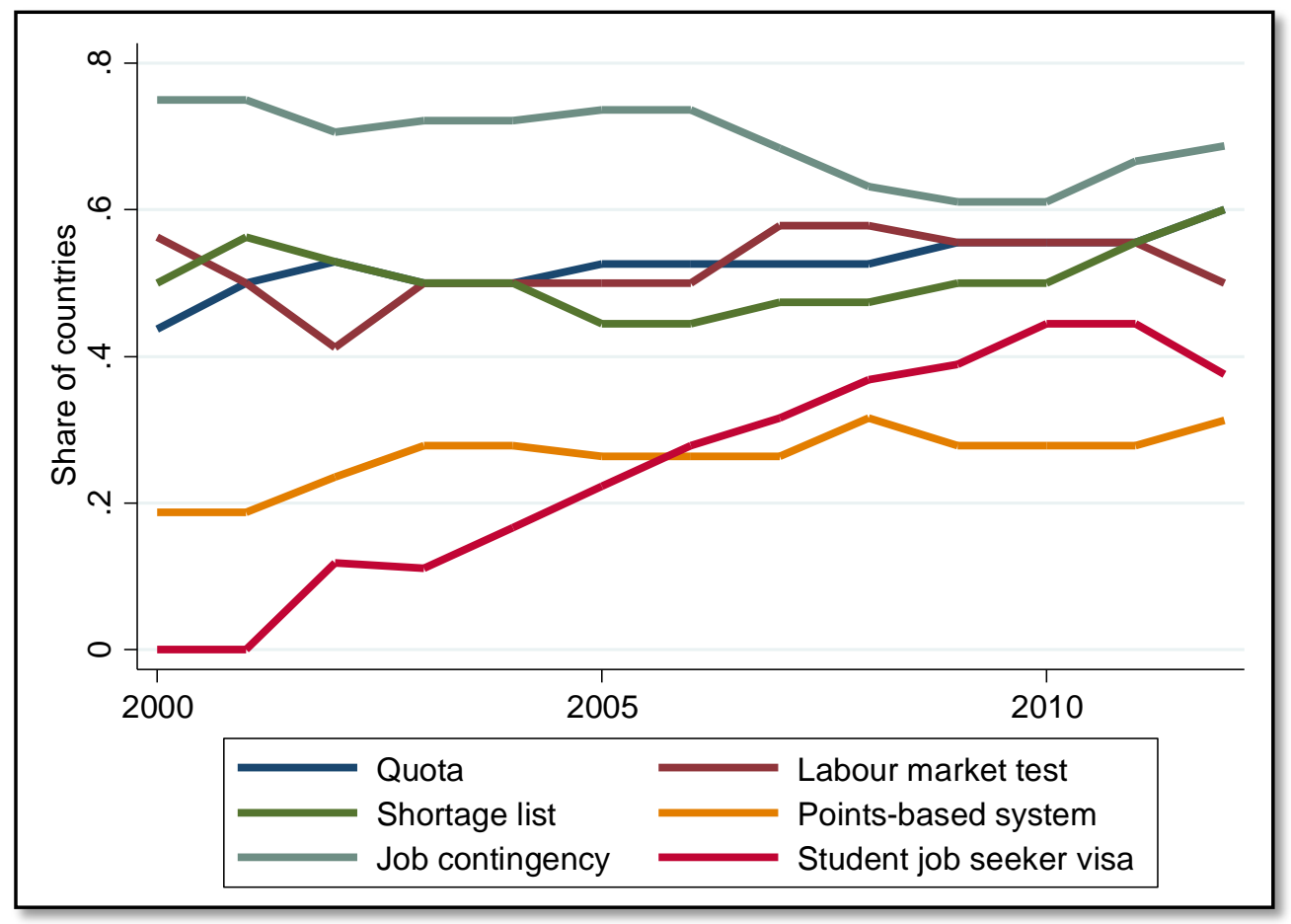

Note: See footnote 11 for list of countries. Appendix A4 reports coding rules.

Figure 3 shows the prevalence of the aforementioned selection policies across 19 OECD destinations between 2000 and 2012. Three-quarters of these countries implement job offer systems, while around half use additional 'demand-driven' policy elements that include shortage lists and labour market tests. Ten countries also use quotas. Points-based systems are used in six countries, namely: Australia, Canada, New Zealand, the Czech Republic, the UK and Japan. The most rapidly diffusing policy instrument is the post-study job seeker visa. In 2000, none of the 19 countries implemented such schemes, while ten years later, almost half of the countries had introduced such measures to retain foreign (-born) graduates. Interestingly, we find little evidence for any policy reversals as a consequence of the global financial and economic crisis. In the wake of the crisis, with fewer jobs available, only the reduced prevalence of job contingency systems is noticeable. This suggests that policy making has to some extent acknowledged the difficulties in acquiring foreign high-skilled workers before entry and that such requirements have been viewed as obstacles for high-skilled workers. Concurrently, some countries have also temporarily reduced the number of occupations on their shortage lists (Cerna and Czaika 2015), although occupational shortage lists have not been abandoned by any of the countries under study. Conversely, several countries have recently introduced shortage lists to manage high-skilled recruitment more effectively.

\section{3 Post-entry migration policies since 2000}

Beyond the selection instruments outlined in the previous sub-section, immigration packages usually contain additional elements that regulate high-skilled immigrants' post-entry rights, and that may also determine the attractiveness of destinations. The prospect of permanent residence, for example, leading to the ability to plan for the longer-term may represent an important incentive for potential migrants. Highskilled migrants are therefore typically offered pathways to permanent residency, which includes immediate settlement rights (e.g. Australia or Canada). Such rights may also apply to the family members of skilled migrants. In some cases, family reunification is only allowed after a specified period of time 
(e.g. Korea or Romania). For most high-skilled migrants, immediate family reunification has become a sine qua non, the absence of which would deter most. More than 80 per cent of the countries under study provide immediate family reunification rights. Similarly, the provision of spousal work rights, either immediately or after a fixed period of time, often prove pivotal in the calculus of would-be migrants. Opportunity to earn two salaries within a household increases the attractiveness of a migration option and provides dual career opportunities and the diversification of family income. As shown in Figure 5, such provisions for the families of migrants have increased in popularity in recent years.

A failure to grant permanency rights upon arrival results in migrants often beginning employment on temporary visas, which constrain workers from changing employer from that which initially sponsored the work permit. Migrants who want to change employer then must apply for a new work visa, often from abroad, which is sponsored by a different employer. The rights to so-called employer portability rights, i.e. the right to change employers without the need to re-apply for a new temporary work permit, are increasingly granted to migrants, as shown in Figure 5, as it makes migration more attractive by eliminating the risk of early termination of the work permit. The opportunity to change employers, or even sectors, allows migrants to respond flexibly to changing labour market conditions, ensuring that migrants can best capitalise on their stay.

Despite expanding post-entry rights to skilled immigrants, governments employ safeguards which often go beyond those limitations imposed on domestic workers in order to insulate native workers from any negative effects of migration, in terms of wage levels and working conditions. Some such restrictions may be motivated by non-economic, nativist goals, for example by limiting the proportion of foreign workers that can be employed in any individual company as in Korea, or in some sectors, as in Israel. Somewhat surprisingly however, recent history in the wake of the global financial crisis has not witnessed significant increases in labour market protection measures (Figure 5).

Figure 4 Skill-selective post-entry policies in 19 destination countries, 2000-2012

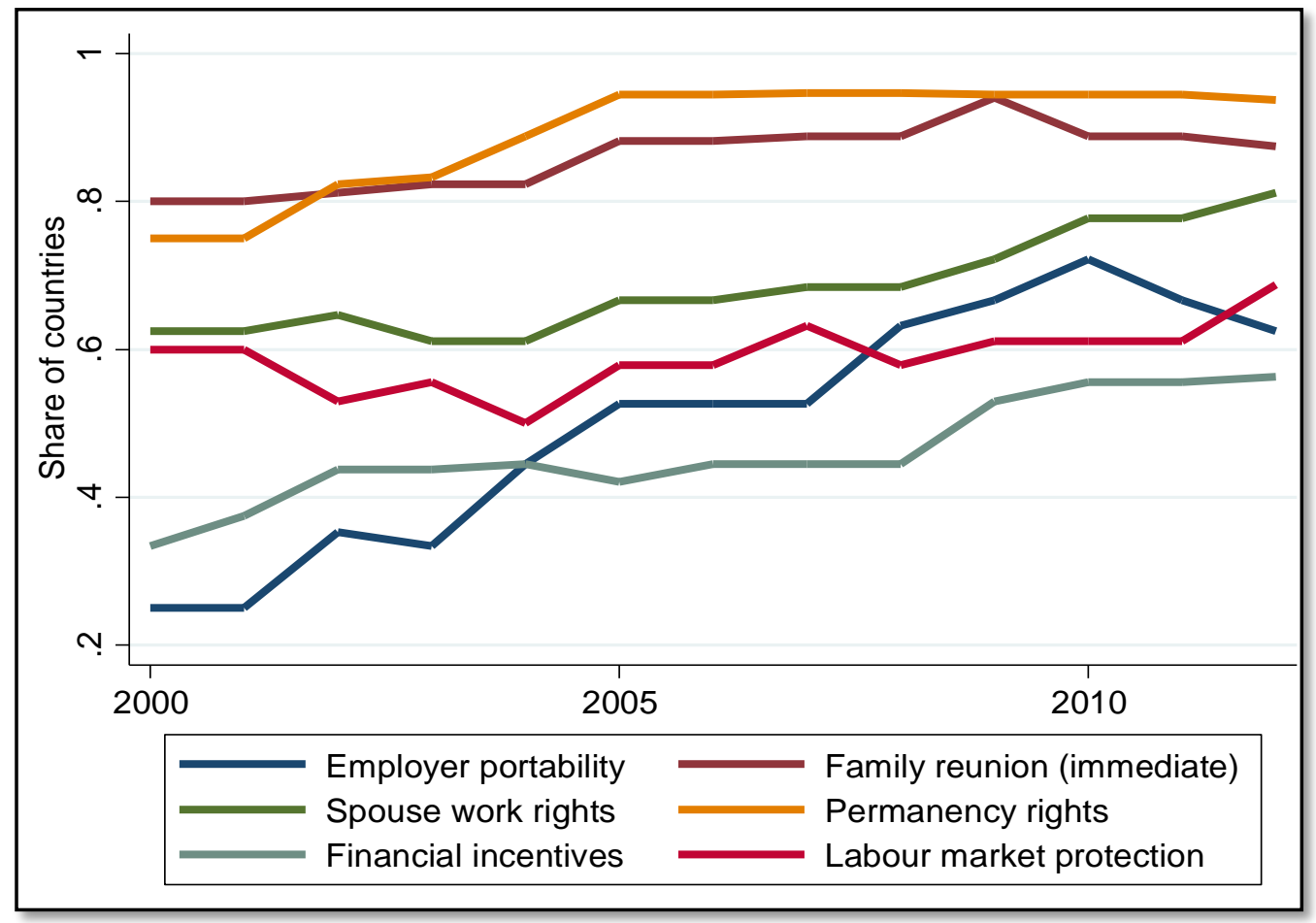

Note: See footnote 11 for list of countries. Appendix A4 reports coding rules. 
Figure 4 also shows that countries increasingly use the offer of financial incentives schemes that include tax exemptions and allowances, to attract and retain high-skilled migrants. Since 2007/08, in particular, the share of countries that have implemented such schemes has been increasing. This seems counterintuitive as these schemes often provide some sort of tax reductions which impact government budgets under stress as a consequence of the economic crisis. However, the trade-off of providing a more attractive environment seems to be considered necessary in order to succeed in the battle for those sought-after (high-income) workers.

\subsection{Bilateral agreements since 2000}

Aside from non-discriminatory unilateral policy elements, many countries have also signed bilateral (and sometimes multilateral) agreements with specific countries, the most prominent of which are those that regulate social security provision, double taxation and tax evasion and the recognition of foreign-earned diplomas. These all serve to facilitate the admission, transition and integration of high-skilled migrants into their new destination. Agreements that govern the recognition of foreign qualifications have probably gained most attention over the last decade; the main goal of which is to facilitate the smooth entry and integration of foreign-trained individuals. Typically, these agreements target specific occupations and/or subject areas and regulate the quality assessment of degree programmes, often by professional associations, to ensure equivalence to domestic degree programmes. Empirical evidence shows that such agreements are effective in fostering the migration of both skilled and non-skilled workers (Czaika and Parsons 2015). As of 2012, recognition of diploma agreements had been signed by more than one-fifth of all country dyads in our dataset (Figure 5).

Figure 5 Bilateral policies of 19 destination countries with 185 origin countries, 2000-2012

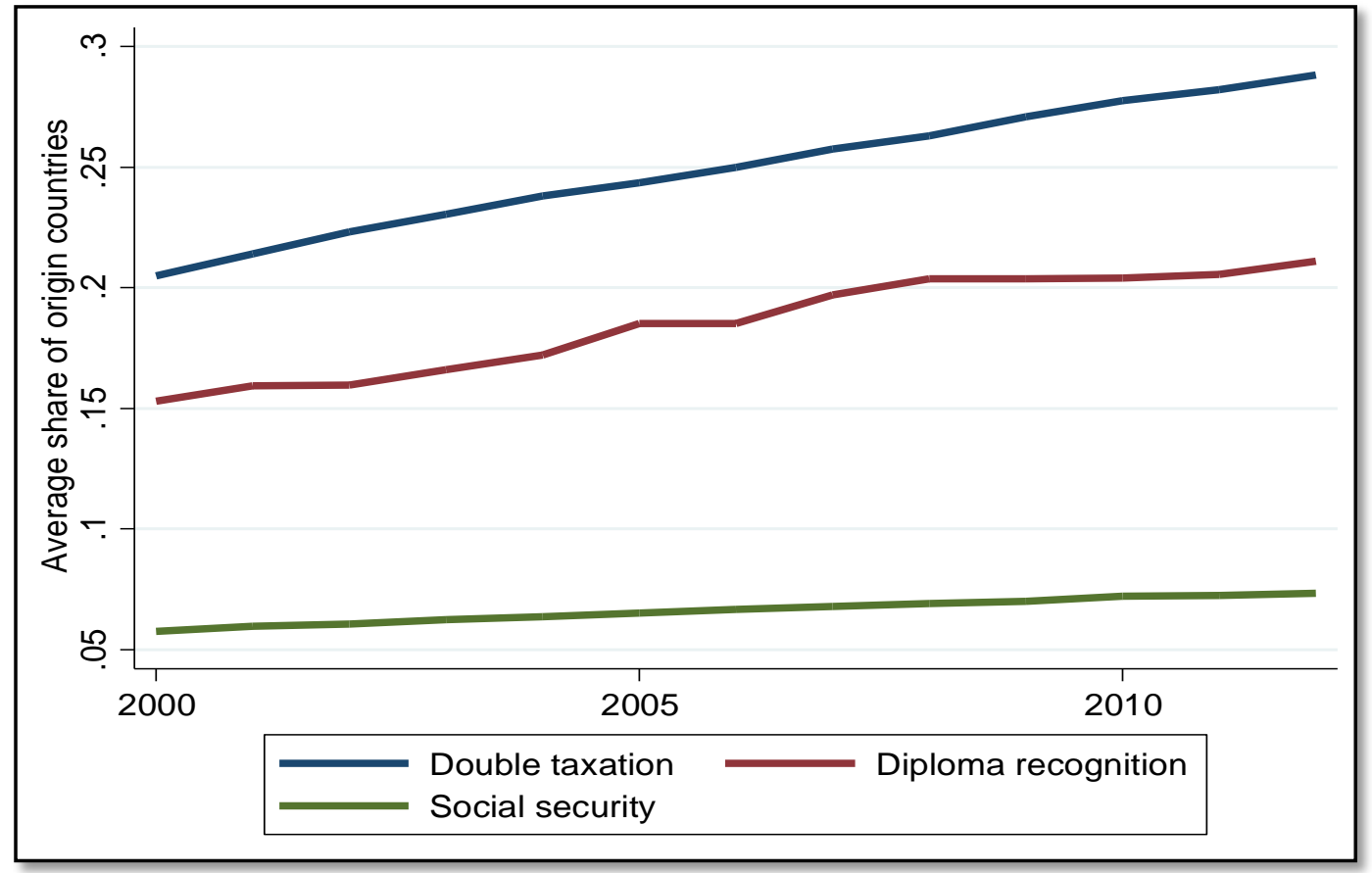

Note: See footnote 11 for list of countries. Appendix A4 reports coding rules.

Double taxation agreements aim to avoid the double taxation of income and are assumed to facilitate transnational careers. Empirical evidence suggests however that such agreements only have very limited results and may in fact deter high-skilled migrants (Czaika and Parsons 2015). Nevertheless, the prevalence of double taxation agreements has increased throughout the 2000s and by 2012 almost a third 
of all bilateral corridors between the 19 destination and 185 origin countries in our sample had implemented such agreements (Figure 5).

Social security agreements rather aim to regulate international rights regarding the equal treatment of the payment of benefits overseas, for example: pensions and their portability, disability benefit, payments to those widowed or to carers and unemployment benefits. These highly complex regulatory packages are increasingly negotiated and implemented between a still small but growing range of countries. In 2012, in about 8 per cent of all bilateral corridors of our dataset such agreements were established, a trend which has slightly increased during the 2000s (Figure 5).

Figure 6 displays composite indices of our three high-skilled migration policy dimensions, which show the extent to which our 19 destination countries have implemented the various aforementioned policy instruments. We distinguish between skill-specific admission ('selection') and post-entry ('attraction') indices, both of which comprise six instruments each. Our bilateral agreements index is rather constructed using the prevalence of double taxation, diploma recognition and social security agreements. Major destination countries have become demonstrably active, and increasingly so across all three policy areas. An increasing number of destination countries are expanding the number of policy instruments they implement in order to attract and select high-skilled migrants. Index scores, defined between zero and one, are calculated as arithmetic means of policy instruments implemented across 19 destination countries by policy area (attraction, selection, bilateral). For instance, an index score of 0.6 represents that the 19 destination countries have implemented 'on average' four out of six attraction and selection policy instruments, respectively, or two out of three types of bilateral agreements.

Figure 6 Attraction versus selection: a HSM policy index, 19 destination countries, 2000-2012

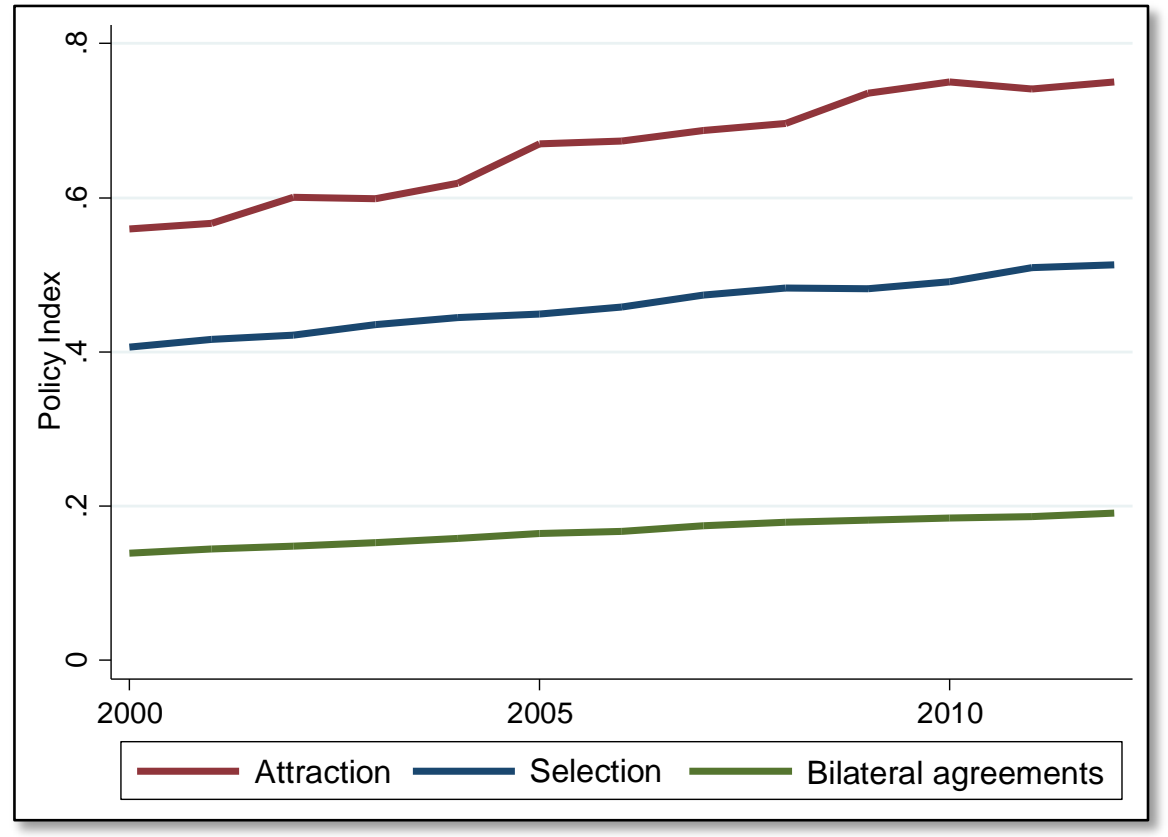

Attraction policies, predominantly in the form of post-entry and employment rights, have become the most widely implemented policy elements. This reflects the broader trend in migration policy making of providing more generous rights to migrants which is partly driven by an expansion of international (humanitarian) obligations and legal norms on the treatment of migrants and migrant workers (Joppke 1998). However, this seems also to be a consequence of the enhancing competition for skilled workers who demand a more attractive legal environment for permanent settlement. This steady expansion of post-entry rights is a longer trend which has been taking place for a few decades (de Haas et al. 2014), 
but it has even slightly accelerated with the onset of the global financial and economic crisis in 2007/08 (Figure 6).

Implementation of skill-selective admission ('selection') policies has been continuously increasing across the 19 destination countries, although at a slower pace than attraction policies. There is no evidence though of a significant reversal in these policies despite a brief 'pause' between 2008 and 2010 in implementing such policies. Finally, bilateral agreements have continuously been used to manage labour migration flows, and apart from the steadily increasing trend, implementation of bilateral labour agreements seem to be completely unaffected by the global economic crisis. But given that negotiation of bilateral agreements can be a tedious process, this absence of a 'crisis-effect' is not surprising.

\section{Conclusion}

We identify enhanced policy making activity in high-skilled migration processes and policies since the 2000s. This seems to have been mainly sparked by continuing and intensifying labour shortages and a structural demand for workers in high-skilled occupations. At the same time, we observe an increasing scholarly interest in this topic due to the progress made on collecting and generating respective migration (stock) data. However, despite the importance generally perceived of the movement of high-skilled workers and the benefits of implementation of policies aimed at attracting high-skilled workers, empirical evidence on the dynamics and interdependence of high-skilled migration flows and policies has remained limited largely due to the difficulty in collating data on either.

This study has presented a new international bilateral database of immigrant labour flows harmonised in terms of the definitions of origin, duration of stay and immigrants' channel of entry. Our data reveal great diversity in the overall size of labour flows, the skill composition of these flows, the continued agglomeration of the international mobility of human capital as well as the increasing diversification of such flows over time. However, we find that the drop in immigration flows into major industrialised countries hit by the financial and economic crisis was rather short-lived and predominantly in the major destinations only. By 2011, numbers on skilled and high-skilled immigrants are largely back to the mid- and long-term trend of increasing high-skilled immigration to major OECD destinations.

This study has also provided an overview of major high-skilled migration policy trends in this area, which are, firstly, the integration of migrant- and employer-driven policy instruments into hybrid systems which ensure the best possible outcome in terms of the number and employability of internationally recruited skilled and high-skilled migrants. Secondly, talent-recruiting countries are increasingly targeting foreign students. Early career recruitment is increasingly seen as a strategy with the highest pay-off in terms of socio-economic integration outcomes of labour migrants. In this respect, liberalisation of study visa issuance, including a more generous provision of post-study visas and student job seeker visas, has been a major policy development during the 2000s. Thirdly, despite the mostly dramatic effects of the global financial and economic crisis on the state of domestic labour markets, a striking observation is that we did not see any significant attempts to restrict skilled immigration. On the contrary, the liberalisation of both admission and post-entry policies has followed similar trends before and after 2007/08. Thus, despite the global economic crisis and its adverse economic impacts e.g. on labour market outcomes, high-skilled migration policies have not seen a major backlash by becoming more restrictive. Despite some fine-tuning adjustments in shortage lists or credit point configurations in the countries with some sort of a points-based system, no significant policy reversal has occurred. Demand for highly-qualified workers has rather intensified in certain occupations and countries continue to become active players in the recruitment of highly skilled migrants. Besides the increasing role of financial incentives such as tax breaks and allowances, countries are increasingly engaged in implementing agreements regulating the mutual recognition of degrees and credentials, hoping that this 
may facilitate the recruitment of foreign-trained workers. At the same time, talent-recruiting countries are increasingly targeting foreign students and graduates. Early career recruitment is increasingly seen as a strategy with the highest pay-off in terms of socio-economic integration and labour market outcomes. In this respect, liberalisation of study visa issuance including a more generous provision of post-study visas remains an ongoing trend largely unaffected by the economic crisis.

Most governments have rather intensified their efforts to make their countries a more attractive place for internationally mobile human capital including investors and businessmen, who are increasingly regarded as a further group of valuable subjects to be attracted. Thus, the 2000s have shown an intensification of high-skilled migration activity in conjunction with a dissemination of skill-specific selection and attraction policies with the aim of recruiting talent for multiple purposes ranging from filling domestic labour market shortages and niches, importing human capital stimuli for national innovation systems, cushioning the demographic transition and ensuring sustainability of welfare systems, and potentially even weakening international competitors on the global talent market. These rationales for implementing more skill-selective and skill-attractive policies are likely to continue over the course of the next decade with significant policy backlashes rather being the exemption when it comes to high-skilled migration policies. 
Appendix Table A1 Overview of the data collected

\begin{tabular}{|c|c|c|c|c|}
\hline Country & Data source & Definition of migrant & Occupational Classification(s) and level of disaggregation & Time period \\
\hline Australia & $\begin{array}{l}\text { Department of Immigration and } \\
\text { Border Protection: Overseas } \\
\text { Arrivals and Departures system }\end{array}$ & $\begin{array}{l}\text { settler arrivals, } \\
\text { permanent additions } \\
\text { by nationality }\end{array}$ & $\begin{array}{l}\text { 1996-2010: Australian Standard Classification of Occupations } \\
\text { (ASCO) Revs. } 1 \text { \& } 2-5 \text { digit } \\
\text { 2010-2012: Australian and New Zealand Standard Classification } \\
\text { of Occupations (ANZSCO) - } 4 \text { digit }\end{array}$ & 2000-2012 \\
\hline Canada & $\begin{array}{l}\text { Citizenship and Immigration } \\
\text { Canada Administrative Data } \\
\text { files }\end{array}$ & $\begin{array}{l}\text { permanent residents } \\
\text { (from abroad) by } \\
\text { nationality }\end{array}$ & $\begin{array}{l}\text { Canadian National Occupational Classification (NOC) } 2011 \text { - } 4 \\
\text { digit }\end{array}$ & 2000-2012 \\
\hline Israel & $\begin{array}{l}\text { Central Bureau of Statistics, } \\
\text { Administrative Data files }\end{array}$ & $\begin{array}{l}\text { immigrants } 15^{+} \text {, by } \\
\text { country of birth }\end{array}$ & $\begin{array}{l}\text { Israeli Standard Classification of Occupations } 1994 \text { (SCO) - } 1 \\
\text { digit }\end{array}$ & 2000-2012 \\
\hline Korea & Employment Visas & nationality & Korean (Employment) Visa Type & 2000-2012 \\
\hline New Zealand & Arrival and Departure cards & $\begin{array}{l}\text { nationality (intention } \\
\text { to stay } 12 \text { months+). } \\
\text { Captures border events } \\
\text { (so no change of status } \\
\text { onshore) }\end{array}$ & $\begin{array}{l}\text { 1978-Mar 1991: New Zealand Standard Classification of } \\
\text { Occupations (NZSCO) } 1968-4 \text { digit } \\
\text { Apr 1991-Sept 2009: New Zealand Standard Classification of } \\
\text { Occupations (NZSCO) } 1995-4 \text { digit } \\
\text { Oct 2009-2012: Australian and New Zealand Standard } \\
\text { Classification of Occupations (ANZSCO) - } 4 \text { digit }\end{array}$ & 2000-2012 \\
\hline Norway & $\begin{array}{l}\text { Population Register (combined } \\
\text { with Register of Employment) }\end{array}$ & $\begin{array}{l}\text { nationality (intention } \\
\text { to stay at least } 6 \\
\text { months) }\end{array}$ & $\begin{array}{l}\text { International Standard Classification of Occupations (ISCO) } 1988 \\
-1 \text { digit }\end{array}$ & 2003-2012 \\
\hline Sweden & $\begin{array}{l}\text { Total Population Register } \\
\text { (combined with Occupation } \\
\text { Register) }\end{array}$ & $\begin{array}{l}\text { nationality (intend to } \\
\text { stay in Sweden for at } \\
\text { least } 12 \text { months) }\end{array}$ & $\begin{array}{l}\text { Swedish Standard Classification of Occupations (2012) based upon } \\
\text { International Standard Classification of Occupations (ISCO) } 2008 \\
-2 \text { digit }\end{array}$ & 2000-2009 \\
\hline Switzerland & $\begin{array}{l}\text { Residence Permits obtained (as } \\
\text { a result of employment) }\end{array}$ & nationality & Swiss Standard Classification of Occupations $1990-5$ digit & 2002-2012 \\
\hline
\end{tabular}




\begin{tabular}{|l|l|l|l|l|}
\hline UK & $\begin{array}{l}\text { Work Permits data + Labour } \\
\text { Force Survey Data (for EU } \\
\text { nationals) }\end{array}$ & nationality & $\begin{array}{l}\text { U.K. Standard Occupational Classification 2000 - 4/5 digit } \\
\text { Labour Force Survey Data (for EU nationals) - 1 digit }\end{array}$ & 2000-2008 \\
\hline US & $\begin{array}{l}\text { I-485 Applications to Register } \\
\text { Permanentr Residence, } \\
\text { supplemented with I-94 } \\
\text { H1B visa data (see text). }\end{array}$ & nationality & U.S. Standard Occupational Classification 2010 (SOC) - 1 digit & 2000-2012 \\
\hline
\end{tabular}




\section{Appendix A2: Occupational concordance for high-skilled category}

The level of disaggregation in the underlying flow data by occupation as received largely determined the extent to which the data could be harmonised. In the end though, a very close harmonisation was increased, one based on the ISCO 2008. The Swedish Standard Classification of Occupations is based on ISCO 2008. The data for Norway were based upon ISCO 1988, which is extremely similar to ISCO 2008, especially when aggregating over the first three major groups. For a second group of countries, Australia, Canada, New Zealand, Switzerland and the UK, the data we received were sufficiently detailed to ensure a precise matching of the occupations. In the case of the UK, however, since the data obtained omitted those that entered the country from the European Union, a further step was needed. To proxy for these workers, we first obtained data on the total long-term gross inflows of migrants by nationality that entered the UK with a definite job to go into, ${ }^{11}$ by various aggregate groups that comprise the EU over time, the EU15, the EU8 and the EU2 from the Office of National Statistics. ${ }^{12}$ To disaggregate these totals, (stock) data from the UK's labour force surveys were used to ascertain the shares of individuals from each constituent national element that comprised each aggregate and further the proportion of skilled people in each migrant corridor in each year. These shares were then applied to the aggregates in order to provide proxies for the omitted data. For Korea, data are available by employment visa, and it was a relatively easy task to simply term occupations as high-skilled should they appear within the first three major groups of ISCO 2008. The data for Israel and the US proved to be hardest to match since we only received data at the 1-digit level. Israel bases its occupational nomenclature on the education level required to fill that position and so we choose to include as high-skilled: Major Group 0: academic professionals, Major Group 1: associate professionals and technicians and Major Group 2: managers. This resulted in a tight fit, except on the very margin, with only a handful of occupations, namely: 'agents (not elsewhere stated)', 'customs, tax and licencing supervising officials', 'tax and customs clerical workers', 'social benefit licencing clerical workers', 'secretarial workers supervisors' and 'general managers of restaurants and hotels' being considered as high-skilled in ISCO but not deemed so in Israel. Similarly we cannot perfectly match our 1-digit data for the US to ISCO. The best we can do is to include Major Group 1: management, professional and related occupations but to exclude Major Group 2: service occupations, since this latter category includes all those working in service occupations regardless of education or skill level, e.g. 'cooks and food preparation workers' and 'baggage porters', 'bellhops' and 'concierges'. The cost of omitting this second category is that some healthcare occupations, for example 'nursing associate professionals' are excluded.

\footnotetext{
${ }^{11}$ Note that this definition is identical to that which we adopt in this working paper.

${ }^{12}$ http://www.ons.gov.uk/ons/rel/migration1/long-term-international-migration/2013/table-3-08.xls.
} 
Appendix Table A2 (contd.): Occupational concordance for high-skilled category, by country of destination

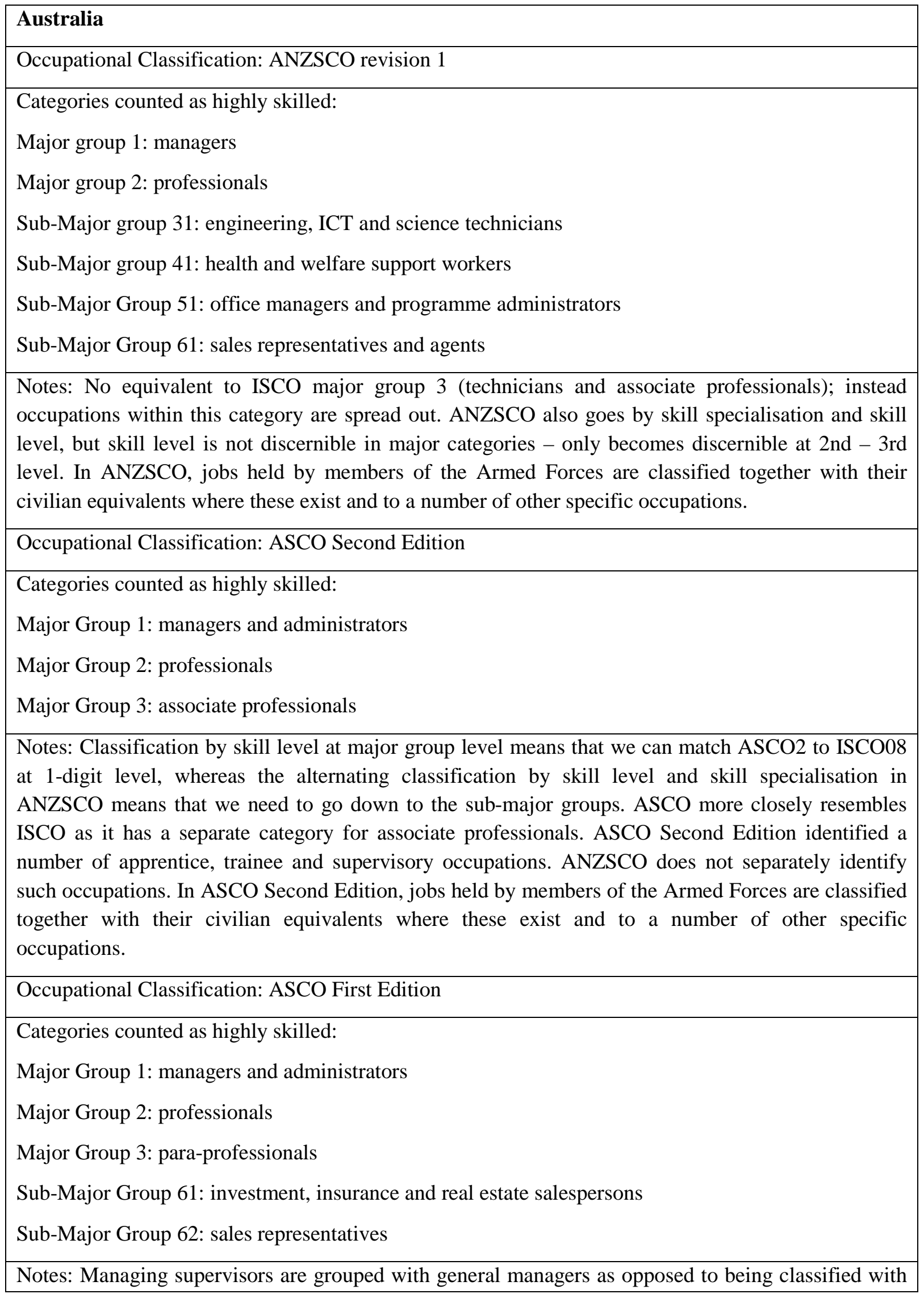


the people that they supervise, as is done in several national classifications. Protective services workers (police, security guards and fire-fighters) are in associate professionals whereas in ISCO they are in service and sales workers. Financial dealers, brokers and agents are not in para-professionals but in service and sales workers. Note that by excluding Sub-Major Group 66 (personal services workers), dental nurses and enrolled nurses will be left out.

\section{Canada}

Occupational Classification: Canadian National Occupational Classification 2011

Categories counted as highly skilled:

Major Group 0: management occupations

Sub-Major Group 11: professional occupations in business and finance

Sub-Major Group 12: skilled administrative and business occupations

Major Group 2: natural and applied sciences and related occupations

Major Group 3: health occupations

Major Group 4: occupations in social science, education, government service and religion

Major Group 5: occupation in art, culture, recreation and sport

Sub-Major Group 92: processing, manufacturing, and utilities, supervisors and skilled operators

Notes: Although in NOC occupations are classified by skill type and skill level (as in ISCO), the Major Groups are organised according to skill type as opposed to skill level which means that in order to get an accurate representation of skilled categories, you need to go down to the sub-major level. For example in Major Group 1, you need to separate the skilled and professional occupations in Business, Finance and Administration from the clerical occupations in Business, Finance and Administration.

Canada NOC goes to great lengths to separate the process control technicians and supervisors from machine operators whereas in other classifications, these two occupations are grouped together based on the product which they manufacture. For example instead of Wood Manufacturing Supervisors and Wood Processing Machine Operators, you only have wood manufacturing occupations.

Canada, unlike many other countries, places trades at the associate skill level but in order to maintain harmony with rest of classification, trades are NOT included.

\footnotetext{
Israel

Categories counted as highly skilled:

Major Group 0: academic professionals

Major Group 1: associate professionals and technicians

Major Group 2: managers
}

Occupational Classification: Israeli Standard Classification of Occupations 1994 
Notes: Occupations are classified based on level of education required for the job

\section{Korea}

Occupational Classification: Employment Visas

Categories counted as highly skilled:

All 'working visas' namely: public official, residence reporter, religious activities, trade and business, job seeking, professor, foreign language instructor, research, technology instructor, particular occupation (law, accounting, medicine), speciality occupations, employment after industrial training

With the exceptions of: intra-company transferees, investors, art and entertainment.

Notes: Short-term occupations (less than 90 days) not included. Trainees (general and industrial) not included because they are more like students

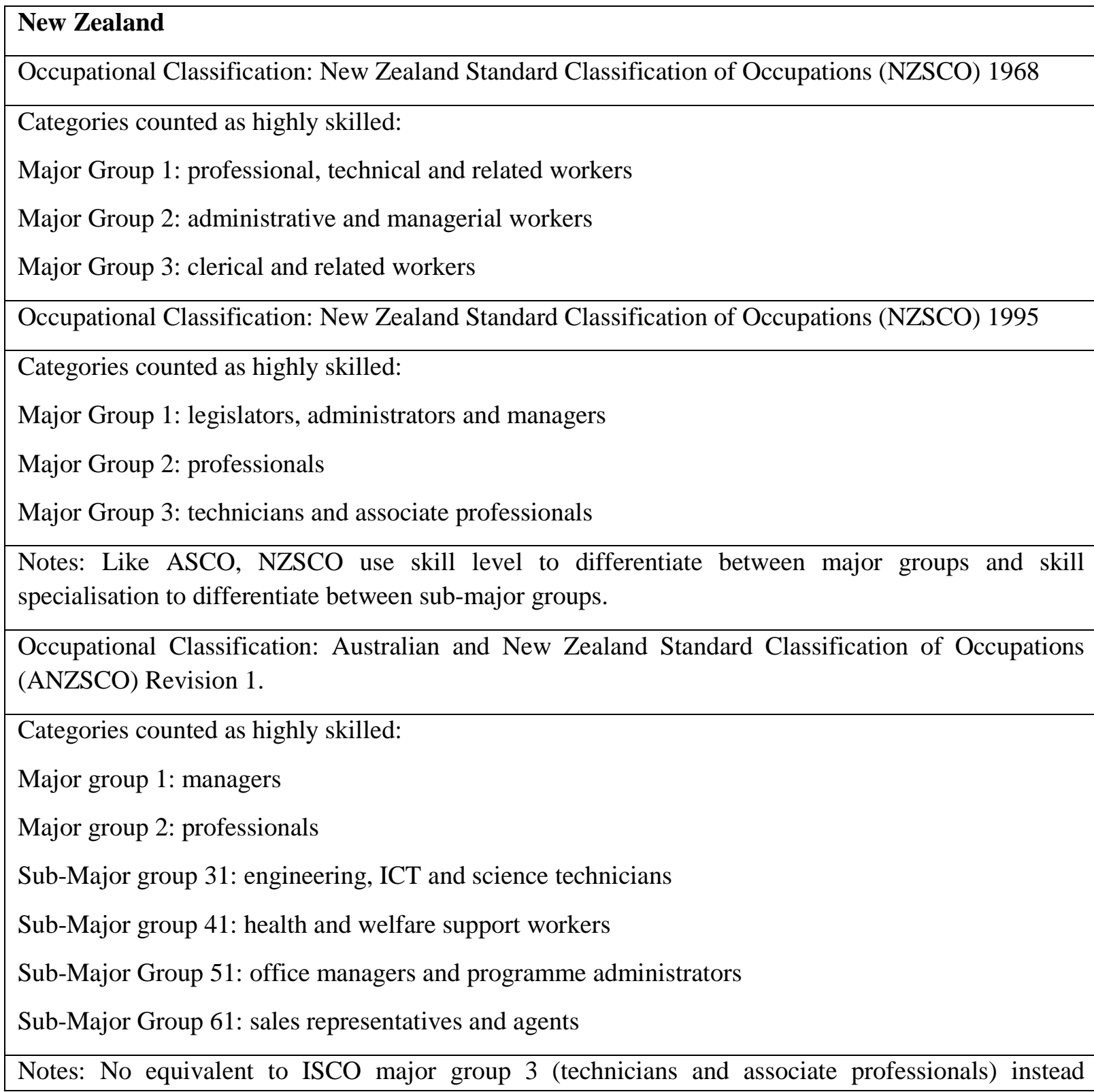


occupations within this category are spread out. ANZSCO also goes by skill specialisation and skill level, but skill level is not discernible in major categories - only becomes discernible at 2nd - 3rd level. In ANZSCO, jobs held by members of the Armed Forces are classified together with their civilian equivalents where these exist and to a number of other specific occupations.

\title{
Norway
}

Occupational Classification: ISCO 1988

Categories counted as highly skilled:

Major Group 1: legislators, senior officials and managers

Major Group 2: professionals

Major Group 3: technicians and associate professionals

Notes: The differences between ISCO 1988 and ISCO 2008

\section{Sweden}

Occupational Classification: Swedish Standard Classification of Occupations (2012)

Categories counted as highly skilled:

Major Group 1: managers, senior officials and legislators

Major Group 2: professionals

Major Group 3: technicians and associate professionals

Notes: This based upon International Standard Classification of Occupations (ISCO) 2008 so constitutes a perfect match.

by total inflow/outflow

\author{
Switzerland \\ Occupational Classification: Swiss Standard Classification of Occupations 1990 \\ Categories counted as highly skilled: \\ Minor Group 291: engineers \\ Minor Group 292: technicians \\ Minor Group 293: technical drawing occupations \\ Minor Group 294: technical personnel \\ Minor Group 321: banking and insurance professionals \\ Minor Group 322: advertising and marketing occupations \\ Minor Group 324: accountants and financial advisers \\ Minor Group 325: brokers, lenders and auctioneers \\ Sub-Major Group 33: large organisation and administration occupations
}


Minor Group 362: legal and judicial occupations

Sub-Major Group 37: media and related occupations

Minor Group 381: musicians

Minor Group 382: entertainment occupations

Minor Group 383: artistic creators

Sub-Major Group 42: health occupations

Sub-Major Group 43: social and spiritual assistance and education occupations

Sub-Major Group 44: teaching and education occupations

Sub-Major Group 45: science occupations (both social sciences and natural sciences)

Notes: Occupations are classified according to area of activity (similar to economic branch classification). Very little distinction based on level of skill. Occupations divided into primary, secondary and tertiary sectors. Therefore, we need to go down to the THIRD level of classification in order to get an accurate representation of high-skilled categories

\section{UK}

Occupational Classification: U.K. Standard Occupational Classification 2000

Categories counted as highly skilled:

521 individual 2-4 digit occupational names individually assigned (concordance is available on request from the author)

\section{US}

Occupational Classification: U.S. Standard Occupational Classification 2010

Categories counted as highly skilled:

Major Group 1: management, professional and related occupations

Notes: US does not make any differentiation between professionals and associate professionals. 


\section{Appendix Table A3: List of countries in the HS migration flow data set}

Origins (185)

Afghanistan, Albania, Algeria, Andorra, Angola, Anguilla, Antigua and Barbuda, Argentina, Australia, Austria, Bahamas, Bahrain, Bangladesh, Barbados, Belgium, Belize, Benin, Bermuda, Bhutan, Bolivia, Botswana, Brazil, British Virgin Islands, Brunei Darussalam, Bulgaria, Burkina Faso, Burundi, Cambodia, Cameroon, Canada, Cape Verde, Cayman Islands, Central African Republic, Chad, Chile, China, Colombia, Comoros, Congo, Cook Islands, Costa Rica, Côte d'Ivoire, Cuba, Cyprus, Czechoslovakia, Democratic Republic of Congo, Denmark, Djibouti, Dominica, Dominican Republic, Ecuador, Egypt, El Salvador, Equatorial Guinea, Eritrea, Ethiopia, Falkland Islands, Federated States of Micronesia, Fiji, Finland, France, Gabon, Gambia, Germany, Ghana, Gibraltar, Greece, Grenada, Guatemala, Guinea, Guinea Bissau, Guyana, Haiti, Honduras, Hong Kong, Hungary, Iceland, India, Indonesia, Iran, Iraq, Israel, Italy, Jamaica, Japan, Jordan, Kenya, Kiribati, Korea, Kuwait, Laos, Lebanon, Lesotho, Liberia, Libya, Luxembourg, Macau, Madagascar, Malawi, Malaysia, Maldives, Mali, Malta, Marshall Islands, Mauritania, Mauritius, Mexico, Mongolia, Montserrat, Morocco, Mozambique, Myanmar, Namibia, Nauru, Nepal, Netherlands, Netherlands Antilles, New Zealand, Nicaragua, Niger, Nigeria, Niue, North Korea, Norway, Oman, Pakistan, Palau, Panama, Papua New Guinea, Paraguay, Peru, Philippines, Poland, Portugal, Puerto Rico, Qatar, Republic of Ireland, Romania, Rwanda, Saint Helena, Saint Kitts and Nevis, Saint Lucia, Saint Vincent and the Grenadines,

San Marino, Sao Tome and Principe, Saudi Arabia, Senegal, Seychelles, Sierra Leone, Singapore, Solomon Islands, Somalia, South Africa, Spain, Sri Lanka, Sudan, Suriname, Swaziland, Sweden, Switzerland, Syria, Taiwan, Tanzania, Thailand, Timor Leste, Togo, Tonga, Trinidad and Tobago, Tunisia, Turkey, Turks and Caicos Islands, Tuvalu, Uganda, United Arab Emirates, UK, US, Uruguay, USSR, Vanuatu, Venezuela, Vietnam, Yemen, Yugoslavia, Zambia, Zimbabwe.

Destinations (10)

Australia, Canada, Israel, Korea, New Zealand, Norway, Sweden, Switzerland, the UK, the US. 
Appendix Table A4: HSM policy database: definitions of variables and coding rules

\begin{tabular}{|c|c|}
\hline Policy instrument & Definition \\
\hline Quotas & $\begin{array}{l}\text { Is there a de facto limit to the number of HS migrants who can enter in } \\
\text { any one year, as a result of policy interventions to this end? }\end{array}$ \\
\hline Shortage list & $\begin{array}{l}\text { Is there a list of in-demand or otherwise valued occupations which is } \\
\text { somehow incorporated into the selection process for HS migrants? }\end{array}$ \\
\hline Labour market test & $\begin{array}{l}\text { Is there a mechanism in place to attempt to ensure the position cannot be } \\
\text { filled by domestic workers? }\end{array}$ \\
\hline Job offer contingency & $\begin{array}{l}\text { Is it possible to enter the country as an HS migrant without first having a } \\
\text { job offer? }\end{array}$ \\
\hline Points-based system & $\begin{array}{l}\text { Is there a selection system that grants applicants points for particular } \\
\text { attributes and allows entry to all those over a particular threshold? }\end{array}$ \\
\hline $\begin{array}{l}\text { Student job seekers' } \\
\text { visa }\end{array}$ & $\begin{array}{l}\text { Do foreign students have the option to stay in the country and look for a } \\
\text { job after their course has finished - either as part of their student visa, or } \\
\text { on a special permit? }\end{array}$ \\
\hline Employer portability & $\begin{array}{l}\text { Do HS migrants have the ability to switch employers without having to } \\
\text { reapply for their permit, after they have been admitted into the country? }\end{array}$ \\
\hline $\begin{array}{l}\text { Family reunification } \\
\text { (immediate or with } \\
\text { delay?) }\end{array}$ & $\begin{array}{l}\text { Do HS migrants have the ability to bring immediate-family members with } \\
\text { them? If so, can they do so when they first migrate, or only after a period } \\
\text { of time? }\end{array}$ \\
\hline $\begin{array}{l}\text { Spouse's work rights } \\
\text { (immediate or with } \\
\text { delay?) }\end{array}$ & $\begin{array}{l}\text { Do the spouses/partners of HS migrants have the ability to work in the } \\
\text { destination country? If so, can they do so when they first migrate, or only } \\
\text { after a period of time? }\end{array}$ \\
\hline $\begin{array}{lr}\text { Permanency } & \text { rights } \\
\text { (immediate or } \text { with } \\
\text { delay?) }\end{array}$ & $\begin{array}{l}\text { Are HS migrants privileged in getting permanent residence or } \\
\text { citizenship? If so, is this because there are permanent-stay entry } \\
\text { categories which are immediately accessible, or is it because they are } \\
\text { privileged in broader applications for permanent residence once they have } \\
\text { met the general requirements? }\end{array}$ \\
\hline Financial incentives & $\begin{array}{l}\text { Are there special financial arrangements (such as tax exemptions, or } \\
\text { allowances) pertaining to HS migrants? }\end{array}$ \\
\hline $\begin{array}{l}\text { Labour } \\
\text { protection }\end{array}$ & $\begin{array}{l}\text { Are there limitations on the conditions under which migrants can be } \\
\text { employed which go above and beyond the limitations on domestic } \\
\text { workers and which appear intended to protect domestic workers or the } \\
\text { labour market? }\end{array}$ \\
\hline $\begin{array}{l}\text { Double } \\
\text { agreement }\end{array}$ & $\begin{array}{l}\text { This variable identifies existing agreements on the avoidance of double } \\
\text { taxation on income and capital, or just on income. The data for double } \\
\text { taxation agreements was mainly drawn from UNCTAD (2011). }\end{array}$ \\
\hline $\begin{array}{l}\text { Diploma/credential } \\
\text { recognition }\end{array}$ & $\begin{array}{l}\text { This variable identifies existing agreements (not necessarily between } \\
\text { legal bodies) of two countries which regulate both the (mutual) }\end{array}$ \\
\hline
\end{tabular}




\begin{tabular}{|l|l|}
\hline agreements & recognition of educational and/or professional credentials. \\
\hline Social \\
agreements & $\begin{array}{l}\text { This variable identifies agreements typically covering equality of } \\
\text { treatment, the payment of benefits abroad, old age pension, disability } \\
\text { support, parenting payment for widowed persons, other insurance } \\
\text { instances, carer payment, occupational accidents, unemployment benefits, } \\
\text { etc. Main source of information was the NATLEX database } \\
\text { (http://www.ilo.org/dyn/natlex/). }\end{array}$ \\
\hline General coding rules & $\begin{array}{l}\text { Data are coded (i) for the highest level of specificity, meaning that the } \\
\text { coding is based upon the policy most relevant to our target population, } \\
\text { even if broader provisions exist that apply to a wider pool of migrants, } \\
\text { and (ii) for the most attractive policy, such that if more than one entry } \\
\text { route exists for high-skilled migrants only the 'most appealing' route is } \\
\text { considered. If this route is eliminated, but others remain, the coding then } \\
\text { applies to the next 'most appealing'. } \\
\text { Similarly, if more appealing routes are introduced, we prioritise them } \\
\text { over the previously existing routes. We further decided to privilege more } \\
\text { detailed sources, whereby in cases when conflicting information was } \\
\text { obtained the source that provides the greatest level of detail is used. In } \\
\text { cases of missing data, the coding assumes policy continuation, on the } \\
\text { basis of legal continuity. Should conditions for entry at two points in time } \\
\text { be highly similar, it is assumed that conditions in the intervening period } \\
\text { remain similar. This approach does risk omitting laws that were } \\
\text { introduced and subsequently revoked in the intervening period. }\end{array}$ \\
\hline \hline
\end{tabular}




\section{References}

Arslan, C., Dumont, J. C., Kone, Z., Moullan, Y., Ozden, C., Parsons, C. and Xenogiani, T. (2014) ‘A New Profile of Migrants in the Aftermath of the Recent Economic Crisis'. OECD Social, Employment and Migration Working Papers No. 160. Paris: OECD.

Artuç E., Docquier, F., Özden, Ç. and Parsons, C. (2014) 'A Global Assessment of Human Capital Mobility: The Role of non-OECD Destinations’. World Development 65: 6-26.

Aydemir, A. (2013) 'Skill-based immigrant selection and labor market outcomes by visa category'. In: Constant, A. F. and Zimmermann, K. F. (eds.) International Handbook on the Economics of Migration. Cheltenham: Edward Elgar.

Bhagwati, J. and Hanson, G. (2009) Skilled immigration today: prospects, problems, and policies. Oxford: Oxford University Press.

Bilsborrow, R. E., Hugo, G., Oberai, A.S. and Zlotnik, H. (1997) International Migration Statistics, Guidelines for Improving Data Collection Systems. Geneva: International Labour Office.

Boeri, T. (2012) 'Introduction’. In: Boeri, T., Brücker, H., Docquier, F. and Rapoport, H. (eds.) Brain Drain and Brain Gain: The Global Competition to Attract High-skilled Migrants. Oxford: Oxford University Press.

Boucher, A. and Cerna, L. (2014) 'Current Policy Trends in Skilled Immigration Policy'. International Migration 52(3): 21-25.

Brücker, H., Capuano, S. and Marfouk, A. (2013) 'Education, gender and international migration: insights from a panel-dataset 1980-2010'.

Cerna, L. and Czaika, M. (2016) 'European Policies to Attract Talent: The Crisis and Highly Skilled Migration Policy Changes’. In: Triandafyllidou, A. and Isaakyan, I. (eds.) High Skill Migration and Recession: Gendered Perspectives. London: Palgrave Macmillan.

Chaloff, J. and Lemaitre, G. (2009) 'Managing Highly-Skilled Labour Migration: A Comparative Analysis of Migration Policies and Challenges in OECD Countries'. OECD Social, Employment and Migration Working Papers No. 79. Paris: OECD.

Chiswick, B. R. (2011). High-skilled immigration in a global labor market. Washington, DC: American Enterprise Institute Press.

Czaika, M., and de Haas, H. (2013) 'The Effectiveness of Immigration Policies'. Population and Development Review 39(3): 487-508.

Czaika, M. and Parsons, C. (2015) 'The gravity of high-skilled migration policies'. IMI Working Paper Series No. 110. Oxford: International Migration Institute.

De Haas, H., Natter, K. and Vezzoli, S. (2014) 'Growing restrictiveness or changing selection? The nature and evolution of migration policies 1946-2013’. IMI Working Paper Series No. 96. Oxford: International Migration Institute.

Docquier, F., and Marfouk, A. (2006) 'International Migration by Educational Attainment (19902000): Release 1.1'. In: Özden, C. and Schiff, M. (eds.) International Migration, Remittances and Development. New York: Palgrave Macmillan.

Docquier, F., Lowell, B. L. and Marfouk, A. (2009) 'A Gendered Assessment of Highly Skilled Emigration’. Population and Development Review 35 (2): 297-321. 
Doomernik, J., Koslowski, R. and Thraenhardt, D. (2009) 'The battle for the brains: Why immigration policy is not enough to attract the highly skilled'. Washington, DC: The German Marshall Fund of the United States.

Duffy, B. and Frere-Smith, T. (2014) 'Perceptions and Reality: Public Attitudes to Immigration.' Ipsos-MORI Social Research Institute.

Dumont, J.C., and Lemaitre, G. (2004) 'Counting immigrants and expatriates in OECD countries: a new perspective'. Mimeo: OECD.

Dumont, J.C., Martin, J. P. and Spielvogel, G. (2007) 'Women on the move: the neglected gender dimension of the brain drain'. IZA Discussion Paper 2920. Bonn: Institute for the Study of Labor.

EMN (2013) 'The application of quotas in EU Member States as a measure for managing labour migration from third countries'. EMN Inform 2103. Brussels: European Commission.

Facchini, G. and Lodigiani, E. (2014) 'Attracting Skilled Immigrants: An overview of recent policy developments in advanced countries’. National Institute Economic Review 229 (1): R3-R21.

Harrison, A., Britton, T. and Swanson, A. (2003) 'Working Abroad: the Benefits from Nationals Working in Other Economies'. Paris: OECD.

International Labour Office (1990) 'International Standard Classification of Occupations, ISCO-88'. Geneva: International Labour Office.

ILO (2009) 'Impact of the Financial Crisis on Finance Sector Workers'. Issues paper for discussion at the Global Dialogue Forum on the Impact of the Financial Crisis on Finance Sector Workers, Geneva, 24-25 February 2009.

Kahanec, M. and Zimmermann, K. F. (2011) 'High-Skilled Immigration Policy in Europe'. In: Chiswick, B. R. (ed.) High-skilled Immigration in a Global Labour Market. Washington, DC: American Enterprise Institute, pp.264-314.

Koslowski, R. (2014). Selective migration policy models and changing realities of implementation. International Migration 52(3): 26-39.

Lowell, B. L. (2005) 'Policies and regulations for managing skilled international migration for work'. In: United Nations Expert Group Meeting On International Migration And Development, Population Division, Department of Economic and Social Affairs, United Nations Secretariat, New York.

OECD (2002) 'Trends in International Migration database’. SOPEMI 2002 Edition. Paris: OECD.

OECD (2008) 'A Profile of Immigrant Populations in the 21st Century: Data from OECD Countries'. Paris: OECD.

Ortega, F. and Peri, G. (2013) 'The Effect of Income and immigration Policies on International Migration’. Migration Studies 1: 1-28.

Özden, Ç., Parsons, C., Schiff, M. and Walmsley, T. (2011) 'Where on earth is everybody? The evolution of global bilateral migration 1960-2000?’ World Bank Economic Review 25(1): 12-56.

Özden, Ç. and Parsons, C. (2015) 'On the economic geography of international migration’. The World Economy. DOI: 10.1111/twec.12264

Papademetriou, D. G., Somerville, W. and Tanaka, H. (2008) 'Hybrid immigrant-selection systems: the next generation of economic migration schemes'. Talent, Competitiveness and Migration 267336. 
Papademetriou, D. G., and Sumption, M. (2013) 'Attracting and Selecting from the global talent pool-policy challenges’. Washington, DC: Migration Policy Institute.

Parsons, C. R., Skeldon, R., Walmsley, T.L. and Winters, L. A. (2007) 'Quantifying the International Bilateral Movements of Migrants'. In: Özden, Ç. and Schiff, M. (eds.) International Migration, Economic Development and Policy. New York: Palgrave Macmillan.

Parsons, C. R., Rojon, S., Samanani, F. and Wettach, L. (2014) 'Conceptualising International Highskilled Migration’. IMI Working Paper Series No. 104. Oxford: International Migration Institute.

Sumption, M. (2013) 'Tackling brain waste: Strategies to improve the recognition of immigrants' foreign qualifications’. Washington, DC: Migration Policy Institute.

United Nations Statistics Division (1998) 'Recommendations on Statistics of International Migration Revision 1’. New York: United Nations.

United Nations (2013) 'Trends in International Migrant Stock: The 2013 Revision'. New York: United Nations Population.

Vezzoli, S., Villares-Varela, M. and de Haas, H. (2014) 'Uncovering international migration flow data: Insights from the DEMIG databases’. IMI Working Paper Series No. 88. Oxford: International Migration Institute.

Wiesbrock, A. and Hercog, M. (2010) 'The Legal Framework for the Highly Skilled Migration to the EU: EU and US Labour Migration Policies Compared'. Maastricht Graduate School of Governance Working Papers 2010/001. 
Editor, UWA Economics Discussion Papers:

Sam Hak Kan Tang

University of Western Australia

35 Sterling Hwy

Crawley WA 6009

Australia

Email: ecoadmin@biz.uwa.edu.au

The Economics Discussion Papers are available at:

1980 - 2002: http://ecompapers.biz.uwa.edu.au/paper/PDF\%20of\%20Discussion\%20Papers/

Since 2001: http://ideas.repec.org/s/uwa/wpaper1.html

Since 2004: http://www.business.uwa.edu.au/school/disciplines/economics

\begin{tabular}{|c|c|c|}
\hline \multicolumn{3}{|c|}{$\begin{array}{l}\text { ECONOMICS DISCUSSION PAPERS } \\
2015\end{array}$} \\
\hline $\begin{array}{l}\text { DP } \\
\text { NUMBER }\end{array}$ & AUTHORS & TITLE \\
\hline 15.01 & Robertson, P.E. and Robitaille, M.C. & $\begin{array}{l}\text { THE GRAVITY OF RESOURCES AND THE TYRANNY OF } \\
\text { DISTANCE }\end{array}$ \\
\hline 15.02 & Tyers, R. & $\begin{array}{l}\text { FINANCIAL INTEGRATION AND CHINA'S GLOBAL } \\
\text { IMPACT }\end{array}$ \\
\hline 15.03 & Clements, K.W. and Si, J. & $\begin{array}{l}\text { MORE ON THE PRICE-RESPONSIVENESS OF FOOD } \\
\text { CONSUMPTION }\end{array}$ \\
\hline 15.04 & Tang, S.H.K. & $\begin{array}{l}\text { PARENTS, MIGRANT DOMESTIC WORKERS, AND } \\
\text { CHILDREN'S SPEAKING OF A SECOND LANGUAGE: } \\
\text { EVIDENCE FROM HONG KONG }\end{array}$ \\
\hline 15.05 & Tyers, R. & $\begin{array}{l}\text { CHINA AND GLOBAL MACROECONOMIC } \\
\text { INTERDEPENDENCE }\end{array}$ \\
\hline 15.06 & $\begin{array}{l}\text { Fan, J., Wu, Y., Guo, X., Zhao, D. and } \\
\text { Marinova, D. }\end{array}$ & $\begin{array}{l}\text { REGIONAL DISPARITY OF EMBEDDED CARBON } \\
\text { FOOTPRINT AND ITS SOURCES IN CHINA: A } \\
\text { CONSUMPTION PERSPECTIVE }\end{array}$ \\
\hline 15.07 & $\begin{array}{l}\text { Fan, J., Wang, S., Wu, Y., Li, J. and } \\
\text { Zhao, D. }\end{array}$ & $\begin{array}{l}\text { BUFFER EFFECT AND PRICE EFFECT OF A PERSONAL } \\
\text { CARBON TRADING SCHEME }\end{array}$ \\
\hline 15.08 & Neill, K. & $\begin{array}{l}\text { WESTERN AUSTRALIA'S DOMESTIC GAS } \\
\text { RESERVATION POLICY THE ELEMENTAL ECONOMICS }\end{array}$ \\
\hline 15.09 & Collins, J., Baer, B. and Weber, E.J. & THE EVOLUTIONARY FOUNDATIONS OF ECONOMICS \\
\hline 15.10 & $\begin{array}{l}\text { Siddique, A., Selvanathan, E. A. and } \\
\text { Selvanathan, S. }\end{array}$ & $\begin{array}{l}\text { THE IMPACT OF EXTERNAL DEBT ON ECONOMIC } \\
\text { GROWTH: EMPIRICAL EVIDENCE FROM HIGHLY } \\
\text { INDEBTED POOR COUNTRIES }\end{array}$ \\
\hline 15.11 & Wu, Y. & $\begin{array}{l}\text { LOCAL GOVERNMENT DEBT AND ECONOMIC } \\
\text { GROWTH IN CHINA }\end{array}$ \\
\hline 15.12 & Tyers, R. and Bain, I. & $\begin{array}{l}\text { THE GLOBAL ECONOMIC IMPLICATIONS OF FREER } \\
\text { SKILLED MIGRATION }\end{array}$ \\
\hline 15.13 & Chen, A. and Groenewold, N. & $\begin{array}{l}\text { AN INCREASE IN THE RETIREMENT AGE IN CHINA: } \\
\text { THE REGIONAL ECONOMIC EFFECTS }\end{array}$ \\
\hline
\end{tabular}




\begin{tabular}{|c|c|c|}
\hline 15.14 & Knight, K. & PIGOU, A LOYAL MARSHALLIAN? \\
\hline 15.15 & Kristoffersen, I. & $\begin{array}{l}\text { THE AGE-HAPPINESS PUZZLE: THE ROLE OF } \\
\text { ECONOMIC CIRCUMSTANCES AND FINANCIAL } \\
\text { SATISFACTION }\end{array}$ \\
\hline 15.16 & Azwar, P. and Tyers, R. & INDONESIAN MACRO POLICY THROUGH TWO CRISES \\
\hline 15.17 & Asano, A. and Tyers, R. & $\begin{array}{l}\text { THIRD ARROW REFORMS AND JAPAN'S ECONOMIC } \\
\text { PERFORMANCE }\end{array}$ \\
\hline 15.18 & Arthmar, R. and McLure, M. & $\begin{array}{l}\text { ON BRITAIN'S RETURN TO THE GOLD STANDARD: } \\
\text { WAS THERE A 'PIGOU-MCKENNA SCHOOL'? }\end{array}$ \\
\hline 15.19 & $\begin{array}{l}\text { Fan, J., Li, Y., Wu, Y., Wang, S., and } \\
\text { Zhao, D. }\end{array}$ & $\begin{array}{l}\text { ALLOWANCE TRADING AND ENERGY CONSUMPTION } \\
\text { UNDER A PERSONAL CARBON TRADING SCHEME: A } \\
\text { DYNAMIC PROGRAMMING APPROACH }\end{array}$ \\
\hline 15.20 & Shehabi, M. & $\begin{array}{l}\text { AN EXTRAORDINARY RECOVERY: KUWAIT } \\
\text { FOLLOWING THE GULF WAR }\end{array}$ \\
\hline 15.21 & $\begin{array}{l}\text { Siddique, A., Sen, R., and } \\
\text { Srivastava, S. }\end{array}$ & $\begin{array}{l}\text { AUSTRALIA-THAILAND TRADE: AN ANALYSIS OF } \\
\text { COMPETITIVENESS AND THE EFFECTS OF THE } \\
\text { BILATERAL FTA }\end{array}$ \\
\hline 15.22 & Tyers, R. & $\begin{array}{l}\text { SLOWER GROWTH AND VULNERABILITY TO } \\
\text { RECESSION: UPDATING CHINA'S GLOBAL IMPACT }\end{array}$ \\
\hline 15.23 & Arthmar, R. and McLure, M. & PIGOU ON WAR FINANCE AND STATE ACTION \\
\hline 15.24 & Wu, Y. & $\begin{array}{l}\text { CHINA'S CAPITAL STOCK SERIES BY REGION AND } \\
\text { SECTOR }\end{array}$ \\
\hline 15.25 & Clements, K. and Si, J. & $\begin{array}{l}\text { ENGEL'S LAW, DIET DIVERSITY AND THE QUALITY } \\
\text { OF FOOD CONSUMPTION }\end{array}$ \\
\hline 15.26 & Chen, S. & $\begin{array}{l}\text { SHIFTS OF DISTORTION AND CORRUPTION OVER } \\
\text { LOCAL POLITICAL CYCLES IN CHINA }\end{array}$ \\
\hline 15.27 & Chen, S. & $\begin{array}{l}\text { THE EFFECT OF A FISCAL SQUEEZE ON TAX } \\
\text { NFORCEMENT: EVIDENCE FROM A NATURAL } \\
\text { EXPERIMENT IN CHINA }\end{array}$ \\
\hline 15.28 & Jetter, M. & $\begin{array}{l}\text { BLOWING THINGS UP: THE EFFECT OF MEDIA } \\
\text { ATTENTION ON TERRORISM }\end{array}$ \\
\hline 15.29 & Tang, S. & $\begin{array}{l}\text { MEDIUM-TERM MACROECONOMIC VOLATILITY AND } \\
\text { ECONOMIC DEVELOPMENT: A NEW TECHNIQUE }\end{array}$ \\
\hline 15.30 & Alim, A., Hartley, P. and Lan, Y. & $\begin{array}{l}\text { ASIAN SPOT PRICES FOR LNG OTHER ENERGY } \\
\text { COMMODITIES }\end{array}$ \\
\hline 15.31 & $\begin{array}{l}\text { Gannon, B., Harris, D., Harris, M., } \\
\text { Magnusson, L., Hollingsworth, B., } \\
\text { Inder, B., Maitra, P, and Munford, L. }\end{array}$ & $\begin{array}{l}\text { NEW APPROACHES TO ESTIMATING THE CHILD } \\
\text { HEALTH-PARENTAL INCOME RELATIONSHIP }\end{array}$ \\
\hline 15.32 & Czaika, M. and Parsons, C. & $\begin{array}{l}\text { THE GRAVITY OF HIGH SKILLED MIGRATION } \\
\text { POLICIES }\end{array}$ \\
\hline 15.33 & $\begin{array}{l}\text { Parsons, C., Rojon, S., Samanani, F, } \\
\text { and Wettach, L. }\end{array}$ & $\begin{array}{l}\text { CONCEPTUALISING INTERNATIONAL HIGH-SKILLED } \\
\text { MIGRATION }\end{array}$ \\
\hline 15.34 & Chen, S. & $\begin{array}{l}\text { VAT RATE DISPERSION AND TFP LOSS IN CHINA'S } \\
\text { MANUFACTURING SECTOR }\end{array}$ \\
\hline 15.35 & Tait, L., Siddique, A. and Chatterjee, I. & $\begin{array}{l}\text { FOREIGN AID AND ECONOMIC GROWTH IN SUB- } \\
\text { SAHARAN AFRICA }\end{array}$ \\
\hline
\end{tabular}




\begin{tabular}{|c|c|c|}
\hline \multicolumn{3}{|c|}{$\begin{array}{l}\text { ECONOMICS DISCUSSION PAPERS } \\
2016\end{array}$} \\
\hline $\begin{array}{l}\text { DP } \\
\text { NUMBER }\end{array}$ & AUTHORS & TITLE \\
\hline 16.01 & Xu, R., Wu, Y. and Luan, J. & $\begin{array}{l}\text { ANALYSIS OF FARMERS’ WILLINGNESS TO ADOPT } \\
\text { GENETICALLY MODIFIED INSECT-RESISTANT RICE IN } \\
\text { CHINA }\end{array}$ \\
\hline 16.02 & $\begin{array}{l}\text { Lia, Y., Fan, J., Zhao, D., Wu, Y. } \\
\text { and Li, J. }\end{array}$ & $\begin{array}{l}\text { TIERED GASOLINE PRICING: A PERSONAL CARBON } \\
\text { TRADING PERSPECTIVE }\end{array}$ \\
\hline 16.03 & Clements, K.W., Lan, Y. and Si, J. & UNCERTAINTY IN CURRENCY MISPRICING \\
\hline 16.04 & Parsons, C. and Vézina, P.L. & $\begin{array}{l}\text { MIGRANT NETWORKS AND TRADE:THE VIETNAMESE } \\
\text { BOAT PEOPLE AS A NATURAL EXPERIMENT }\end{array}$ \\
\hline 16.05 & Chang, S., Connelly, R. and Ma, P. & $\begin{array}{l}\text { WHAT WILL YOU DO IF I SAY ‘I DO’?: THE EFFECT OF } \\
\text { THE SEX RATIO ON TIME USE WITHIN TAIWANESE } \\
\text { MARRIED COUPLES }\end{array}$ \\
\hline 16.06 & $\mathrm{Yu}, \mathrm{F}$. and $\mathrm{Wu}, \mathrm{Y}$. & $\begin{array}{l}\text { BIASES IN PATENT EXAMINATION AND FIRMS' } \\
\text { RESPONSES: EVIDENCE FROM THE } \\
\text { PHARMACEUTICAL INDUSTRY }\end{array}$ \\
\hline 16.07 & $\begin{array}{l}\text { Fan, J., Li, J., Wu, Y., Wang, S. and } \\
\text { Zhao, D. }\end{array}$ & $\begin{array}{l}\text { THE EFFECTS OF ALLOWANCE PRICE ON ENERGY } \\
\text { DEMAND UNDER A PERSONAL CARBON TRADING } \\
\text { SCHEME }\end{array}$ \\
\hline 16.08 & Golley, J., Tyers, R. and Zhou, Y. & $\begin{array}{l}\text { CONTRACTIONS IN CHINESE FERTILITY AND } \\
\text { SAVINGS: LONG RUN DOMESTIC AND GLOBAL } \\
\text { IMPLICATIONS }\end{array}$ \\
\hline 16.09 & McGrath, G. and Neill, K. & $\begin{array}{l}\text { FOREIGN AND DOMESTIC OWNERSHIP IN WESTERN } \\
\text { AUSTRALIA'S GAS MARKET }\end{array}$ \\
\hline 16.10 & Clements, K.W. and Si, J. & SIMPLIFYING THE BIG MAC INDEX \\
\hline 16.11 & Priyati, R.Y. and Tyers, R. & $\begin{array}{l}\text { PRICE RELATIONSHIPS IN VEGETABLE OIL AND } \\
\text { ENERGY MARKETS }\end{array}$ \\
\hline 16.12 & Wu, J., Wu, Y. and Wang, B. & $\begin{array}{l}\text { THE GREENNESS OF CHINESE CITIES: CARBON } \\
\text { DIOXIDE EMISSION AND ITS DETERMINANTS }\end{array}$ \\
\hline 16.13 & $\begin{array}{l}\text { Arslan, C., Dumont, J.C., Kone, Z., } \\
\text { Özden, Ç., Parsons, C. and } \\
\text { Xenogiani, T. }\end{array}$ & $\begin{array}{l}\text { INTERNATIONAL MIGRATION TO THE OECD IN THE } \\
\text { TWENTY-FIRST CENTURY }\end{array}$ \\
\hline 16.14 & Tomioka, K. and Tyers, R. & $\begin{array}{l}\text { HAS FOREIGN GROWTH CONTRIBUTED TO } \\
\text { STAGNATION AND INEQUALITY IN JAPAN? }\end{array}$ \\
\hline 16.15 & Donovan, J. and Hartley, P. & $\begin{array}{l}\text { RIDING THE IRON ORE CYCLE: ACTIONS OF } \\
\text { AUSTRALIA'S MAJOR PRODUCERS }\end{array}$ \\
\hline 16.16 & Czaika, M and Parsons, C. & $\begin{array}{l}\text { HIGH-SKILLED MIGRATION IN TIMES OF GLOBAL } \\
\text { ECONOMIC CRISIS }\end{array}$ \\
\hline
\end{tabular}

